University of Louisville

ThinkIR: The University of Louisville's Institutional Repository

Electronic Theses and Dissertations

$12-2010$

\title{
Methods for focusing on customer orientation in the early phases in the innovation process.
}

Philipp Cimander 1978-

University of Louisville

Follow this and additional works at: https://ir.library.louisville.edu/etd

\section{Recommended Citation}

Cimander, Philipp 1978-, "Methods for focusing on customer orientation in the early phases in the innovation process." (2010). Electronic Theses and Dissertations. Paper 253.

https://doi.org/10.18297/etd/253

This Master's Thesis is brought to you for free and open access by ThinkIR: The University of Louisville's Institutional Repository. It has been accepted for inclusion in Electronic Theses and Dissertations by an authorized administrator of ThinkIR: The University of Louisville's Institutional Repository. This title appears here courtesy of the author, who has retained all other copyrights. For more information, please contact thinkir@louisville.edu. 
METHODS FOR FOCUSING ON CUSTOMER ORIENTATION IN THE

EARLY PHASES IN THE INNOVATION PROCESS.

\author{
By \\ Philipp Cimander \\ A Thesis \\ Submitted to the Faculty of the \\ Graduate School of the University of Louisville \\ in Partial Fulfillment of the Requirements \\ for the Degree of \\ Master of Science \\ Department of Industrial Engineering \\ University of Louisville \\ Louisville, Kentucky
}

December 2010 


\section{Copyright 2010 by Philipp Cimander}

All rights reserved 

METHODS FOR FOCUSING ON CUSTOMER ORIENTATION IN THE

EARLY PHASES IN THE INNOVATION PROCESS.

By

Philipp Cimander

A Thesis Approved on

July 01, 2010

by the following Thesis Committee:

Professor Dr. Gerald Evans, Thesis Director

Professor Dr. William E. Biles

Dr. Tim Hardin 


\section{ACKNOWLEDGEMENTS}

I would like to thank my advisor Professor Dr. Gerald Evans for his guidance in developing my thesis and his advice in the process of writing it.

I would also like to thank my parents for their unlimited support throughout my educational and professional career. Without them, I would not be where I am today.

Special thanks I would like to express to my future wife Agnes, who encouraged and supported me in the last year to an unbelievable extent and thus gave me the strength to write my thesis. 


\section{ABSTRACT \\ METHODS FOR FOCUSING ON CUSTOMER ORIENTATION IN THE EARLY PHASES IN THE INNOVATION PROCESS.}

\section{Philipp A. Cimander}

\section{July 1, 2010}

A constant flow of innovative products which meets the needs of customers and therefore is a monetary success for the inventing organization is important for the long term success of organizations, especially in modern dynamic markets. As resources for innovation projects in organizations are generally limited it is important to choose the right ideas which are followed and later brought to the market. Therefore it is important to integrate external people at the beginning of the innovation process. The following methods all meet this requirement: Models for Positioning compare different attributes of existing or potential products or applications, the Empathic Design Method observes customers using existing products to gain information about future products and the Lead User Approach generates mainly radical innovations by bringing together test persons with very different backgrounds. The developed recommendation matrix based on innovation motives of an organization (e.g. degree of novelty, time frames, change of markets, etc.) and provides recommendations for the selection of a method. As a result, this matrix in combination with other developed factors of differentiation (e.g. complexity of method, availability of resources, etc.) provides a decision guideline for an organization. 


\section{LIST OF TABLES}

PAGE

Table 1. Factors of Differentiation between Methods (own illustration)..............63

Table 2. Recommendation Matrix for Usage of Methods (own illustration)...........66 


\section{LIST OF FIGURES}

PAGE

Figure 1. Importance of Customer Orientation in the Product Development (Lüthje, 2003).

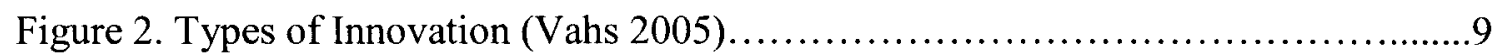

Figure 3. Five conceptual levels of a product (Kotler, Bliemel, 1999) ....................10

Figure 4. Classification of processes (Vahs 2005) ................................12

Figure 5. Aims of Process Innovations (Fink, 2005) .....................................13

Figure 6. Degree of novelty (Reichwald, 2009) ....................................16

Figure 7. Phase-Review-Process (Hughes, Chafin, 1996) ...............................18

Figure 8. Stage-Gate-Process of the $2^{\text {nd }}$ Generation (Cooper, Kleinschmidt, 1990).......19

Figure 9: Process model by Ulrich and Eppinger (Ulrich, Eppinger, 1995) ................20

Figure 10. $3^{\text {rd }}$ Generation Stage-Gate-Process (Cooper, 1996) .........................21

Figure 11. Simultaneous activities in the Innovation Process (Crawford, 1994)...........22

Figure 12. Value Proposition Cycle (reprinted from Hughes and Chafin, 1996)............23

Figure 13. Model of Innovation Process (Herstatt, Verworn 2003).....................24 
Figure 14. Ideas for Innovations as a combination of problems and

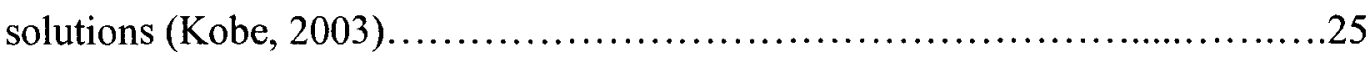

Figure 15. Early Phases in the Innovation Process (Herstatt, Verworn, 2003) ..............28

Figure 16. Positioning of car brands in perception matrix..............................33

Figure 17. Possible desired change of position of Volkswagen............................35

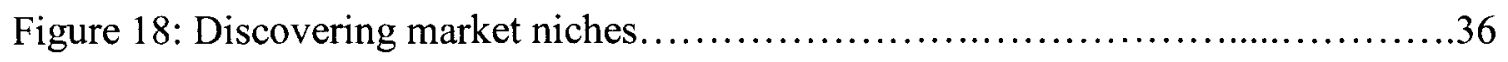

Figure 19: Phases of Emphatic Design Process...........................................39

Figure 20. Innovations by lead users precede equivalent commercial

products (reprinted from von Hippel, 2005) ................................50

Figure 21. User driven innovations (von Hippel, et al., 1999)..........................54

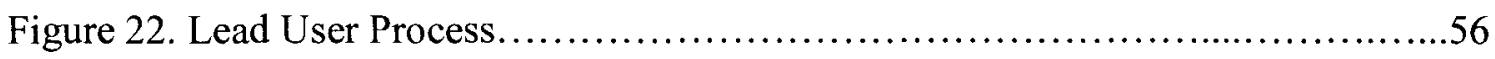

Figure 23. Example of a lead user identification...................................58

Figure 24: Search for lead users by networking approach (Lüthje, 2003)...................60 
TABLE OF CONTENTS

PAGE

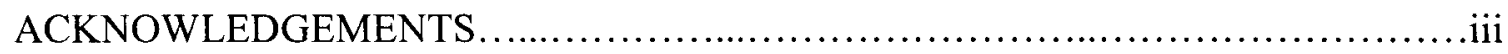

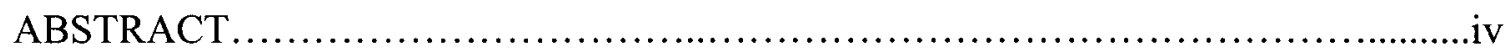

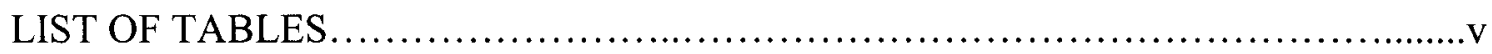

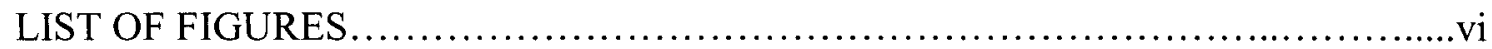

CHAPTER 1 - INTRODUCTION .............................................

1. Customer Orientation as key factor in the early stages of the Innovation Process ...1

CHAPTER 2 - LITERATURE REVIEW ...................................

2. Innovation and Innovation Methods...........................................

2.1. Innovation Process....................................................

2.1.1. Definition of Innovation...........................................

2.1.2. Fields of Innovation............................................ 9

2.1.3. Differentiation by Types of Innovation.............................

2.1.4. Differentiation by Degree of Novelty .............................. 14

2.1.5. Models of the Innovation Process................................... 17

2.1.6. Phases in the Innovation Process......................................23

2.1.7. Definition of the Early Phases in the Innovation Process..............28

2.1.8. Characteristics of the Early Phases of the Innovation Process...........30 
2.2. Methods for Customer Orientation in the Early Phases of the Innovation

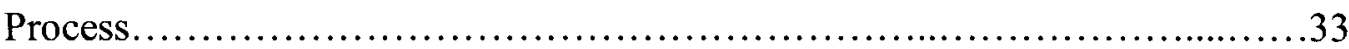

2.2.1. Models for Positioning ................................................

2.2.2. Empathic Design.................................................

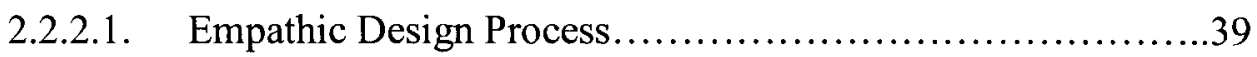

2.2.2.2. Gained Information by Empathic Design....................44

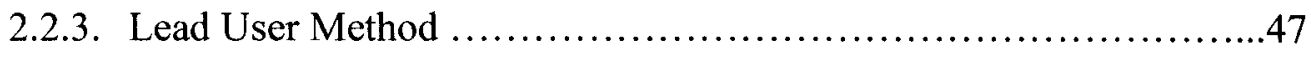

2.2.3.1. Limitation of Market Research.............................48

2.2.3.2. Definition of Lead Users.....................................49

2.2.3.3. Motivation of Lead Users..................................51

2.2.3.4. Examples of Lead User Driven Innovations....................52

2.2.3.5. Design of Lead User Process..................................55

CHAPTER 3 - RECOMMENDATION MATRIX..............................66

3. Recommendation Matrix for Usage of Methods............................62

3.1. Factors of Differentiation between Methods...............................62

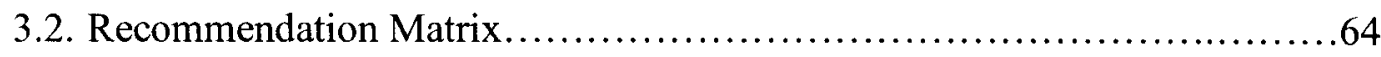

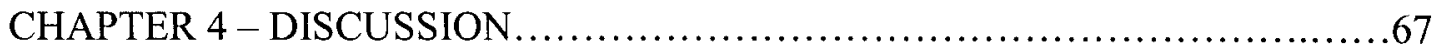

4. Discussion of Recommendation Matrix..........................................67

CHAPTER 5 - SUMMARY AND CONCLUSIONS..............................71

5. Summary and Conclusions................................................... 


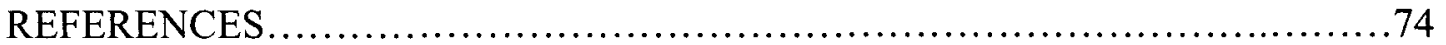

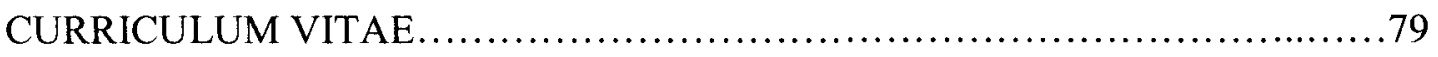




\section{CHAPTER 1 - INTRODUCTION}

\section{Customer Orientation as key factor in the early stages of the Innovation Process}

Organizations that are operating in dynamic markets are in a discrepancy. On the one hand it is generally known, accepted and proved that the development and marketing of innovations is one of the main factors that ensure the success of a company. Therefore innovation is one of the most important drivers for growth and the long term success and survival of a company. On the other hand the rate of products which are launched to the market and are not accepted by customers and therefore represent a loss to the organization (flop rate) is very high in every industry.

In the consumer industry, flop rates of more than $80 \%$ or even $90 \%$ are cited, in Business-to-Business markets $60 \%$ or higher ratios are known (Vahs, Burmester, 2005). How large the number exactly is does not really matter and the main point is very clear: Innovation is on the one hand absolutely necessary for the future of the organization but on the other hand has to be managed as efficiently as possible to save money for the organization. In this context it does not matter whether we are considering product innovations or process innovations. Depending on the type of organization the effects of a flop in a product or an adapted new process in the organization can have the same devastating effect on the future success of the organization. Therefore the conclusions are 
the same even if the stages in the innovation process may be different. To simplify matters, we consider product innovation and therefore include the customer oriented process innovation as another "type" of product innovation, assuming that in the eyes of a customer a new service / process is subjectively very comparable to a tangible product it can be accepted by the customer and he is willing to pay for it (in different ways) or not.

One success factor is generally accepted in any case: The orientation to the customers' needs or wishes increases the possibility of market success of the innovation, the future product. Having this fact, the high flop rates and the high costs of development in mind, strategies and concepts are needed to raise the likelihood of market success of innovative products. In this context it is very often requested to focus all research and development activities on the need of potential customers. Ultimately only new products that have a perceptible added value in the eyes of the customer in comparison to competitors' products have a chance to be successful and refinance investments and generate profit for the organization. Very often this leads to the situation that organizations are hardly able to "think out of their box". This means that they are very focused on their actual customers, their actual product solutions, their actual markets, etc. In many cases this limits the chance of being innovative in the context of exploring new fields of customers or products. This generally leads to the fact that "real" innovations are very rare.

The sum of the mentioned facts and influences leads to the question as to which methods the customer orientation in the innovation process can be ensured. To grant the efficiency of the whole process the customer has to be integrated at the beginning of the process. 
This is important regarding the flop rate and the costs for developments in products which will never be finished in the future due to lacking customer acceptance.

Therefore the early stages of the innovation process have to be clearly defined. The challenge in the early stages in the innovation process is to identify unknown or unconscious customer needs and to transform them into possible solutions that can be sold. In contrast to later stages in the innovation process one cannot at the beginning work with prototypes or samples which can be presented to or be discussed with customers. The real idea behind the customer integration in the early stages of the innovation process is to explore hidden needs and requirements of the customer regarding not yet developed solutions.

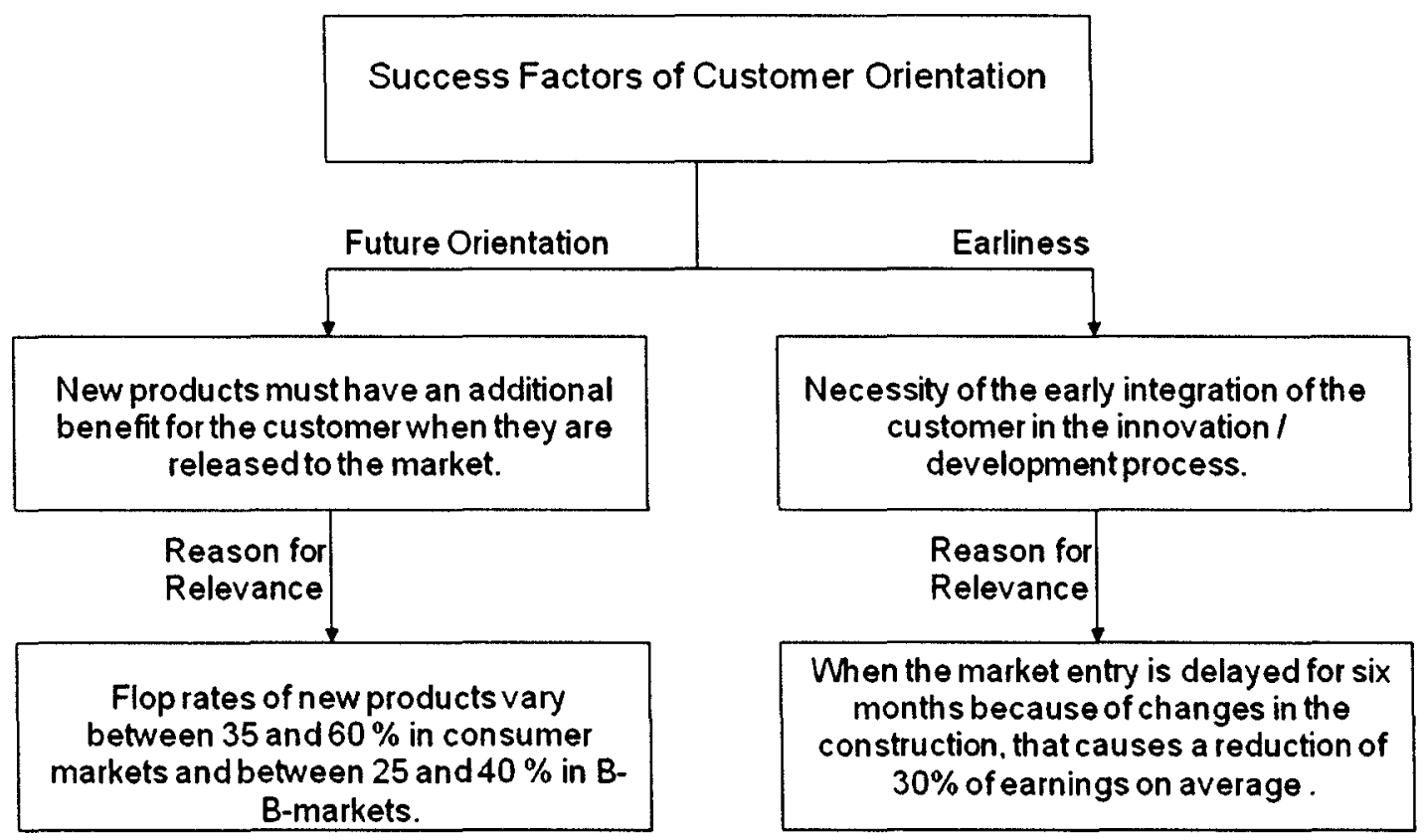

Figure 1. Importance of Customer Orientation in the Product Development (Lüthje, 2003) 
This thesis will clearly define the early stages of the innovation process and point out why these stages are so important for the potential success of the innovation. Furthermore several methods for integrating the customer in the innovation process will be analyzed. One possibility is models for positioning. For the development of new ideas existing products are placed in a perceptual map. The axes represent product features which are relevant for the buyers' decision. Depending on the spreading of the products the company can gain important insights on niches for possible products.

Another possibility is the empathic design method. Very often customers are not aware of future products or possibilities of changing or improving existing solutions because they are too familiar with the existing products or solutions. Empathic design has the goal to improve existing solutions by observing customers at their usual use of existing products. The goal is to find latent customer needs.

Another very common method to discover the future needs of the customer is the lead user method. Many existing methods in the search of innovations involving customers do not lead to the expected results. The "representative" customer seems not to be able to mentally get away from the presently available product and to formulate possible needs which forecast future trends in the product segment. In the lead user method the organization searches for a special type of person (not an existing customer) who is in a special way qualified to contribute to the development of new products. These people have a feeling of needs which will be widespread in the future, much earlier than the main part of the existing customers of today. 
This thesis focuses on these selected methods for the integration of customers, potential customers or non-customers at the beginning of the innovation process. Beside these methods other methods also exist, but the main question for organizations in the search for innovation ideas remains the same: Which method should the organization use? Therefore beside the detailed description of the methods this thesis will also give recommendations for the selection of a method. The developed statements in the recommendation matrix should in a very operative way and in step with present-day practice question the motivation for the planned innovation project of an organization. Depending on the main motivation of the organization the applicable method is recommended and possible second choice alternatives are illustrated. Given the case that there is a stand-off between two methods a matrix of factors of differentiation can in addition help the organization to decide between the possible methods or to check if a selected method is feasible in the organization. The developed recommendation matrix in combination with the described factors of differentiation provides a practical guideline for the decision process in an organization for one innovation method which includes the customer at the beginning of the process and therefore enhances the chance of success of the later product.

After a brief description of the necessity of innovation for any organization and a short overview of the different methods for customer integration in the innovation process in Chapter 1, Chapter 2 provides a literature review about the innovation process. After a short definition of innovation and the differentiation between several types of innovation, different theoretical models of the innovation process are described. Afterwards the different phases of the innovation process are defined and the early stages of the 
innovation process and their characteristics are pointed out. Furthermore in Chapter 2 the innovation methods models for positioning, empathic design and the lead user technique are presented and examples are given. In the third chapter a recommendation matrix for the usage of the described methods is developed and discussed in Chapter 4. In Chapter 5 the author provides a summary and a conclusion on the integration of customers in the early stages of the innovation process and the choice of the innovation method as success factors for an organization. 


\section{CHAPTER 2 - LITERATURE REVIEW}

2. Innovation and Innovation Methods

2. 1. Innovation Process

\subsection{Definition of Innovation}

"Innovation" originally meant "novation" or "reformation". The word comes from the Latin words novus "new" and innovatio "something newly created". One decides between Invention and Innovation. An invention is not yet an innovation by definition. Only if an invention is successful in the view of the organization and the market one can call it an innovation (Hartschen et al., 2009).

The power of innovation of an organization is an important driver of its success and in a very high degree represents the value of the organization. Innovation leads to growth and increased profitability by increasing the customer value on a very attractive price level in the view of the organization. In the author's view the biggest challenge is to keep pace with highly dynamic markets. Therefore a constant flow of new, innovative and successful products and services is necessary. This is the reason why an organization has to stay dynamic and consistently has to adapt its portfolio to the actual and future needs of the market. 
But what does "being innovative" now mean? An innovative organization is open for changes. It has the ability to perceive signals for change early and to transform them into business ideas and projects. Therefore important factors are the willingness to adjust the management and organizational structures to new needs and to realize projects in a disciplined and coordinated way. This organization then openly communicates successes and, on the other hand, also has professionalism in the dealing with mistakes. Through all hierarchies the personnel is involved in the (innovation) processes and becomes motivated. As it can be very difficult to estimate the innovation power of an organization, the following questions can help in a first evaluation of the situation of an organization:

- Does the organization have a portfolio of competitive products for the future to prevent the inherent reduction of price and margin in the market?

- With respect to the existing R\&D projects - are those enough and do they have the potential to create successful products of the future?

- Are there major delays in innovation projects or major budget overruns?

- Is there an efficient cooperation among the departments' Research \& Development, Production, Marketing and Sales especially in innovation projects?

- Are there enough internal competencies and resources to ensure that the organization can handle innovation projects and introduce the resulting products to the market? 


\subsubsection{Fields of Innovation}

Modern Innovations Management no longer has a focus on the development of good products and services. The modern view of innovation includes, as mentioned before, the idea of success in comparison with the market and competitors. Therefore modern innovations management has an effect on the different parts of the organization and their interfaces between themselves and their counterparts outside the organization. Hence, a differentiation of the fields of innovation is necessary.

\subsubsection{Differentiation by Types of Innovation}
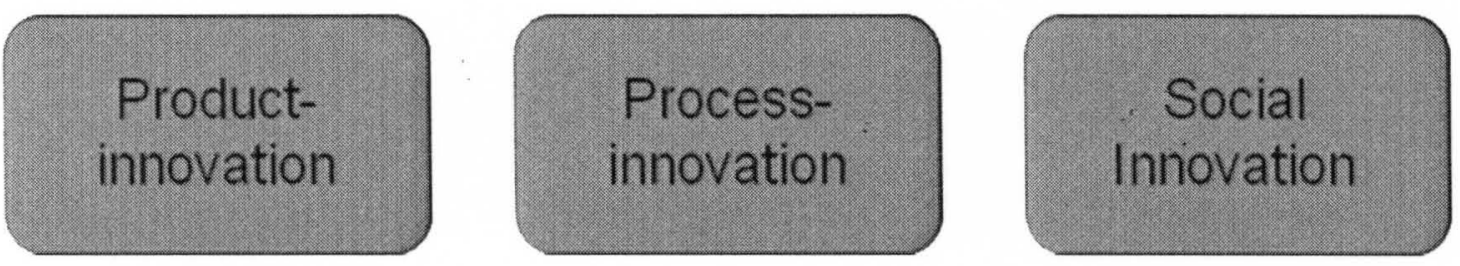

Figure 2. Types of Innovation (Vahs 2005)

\section{Product Innovation}

A product innovation directly relies on innovations in the fields of product development. As already defined at the beginning, "product" in this context means every performance supplied by the organization to the market or to existing or future customers. Therefore it can be a material product or a service but in any case offers some kind of value for the 
customer. To have the right positioning for its products in the market the organization must associate its products with of the following categories (Kotler and Bliemel, 1999):

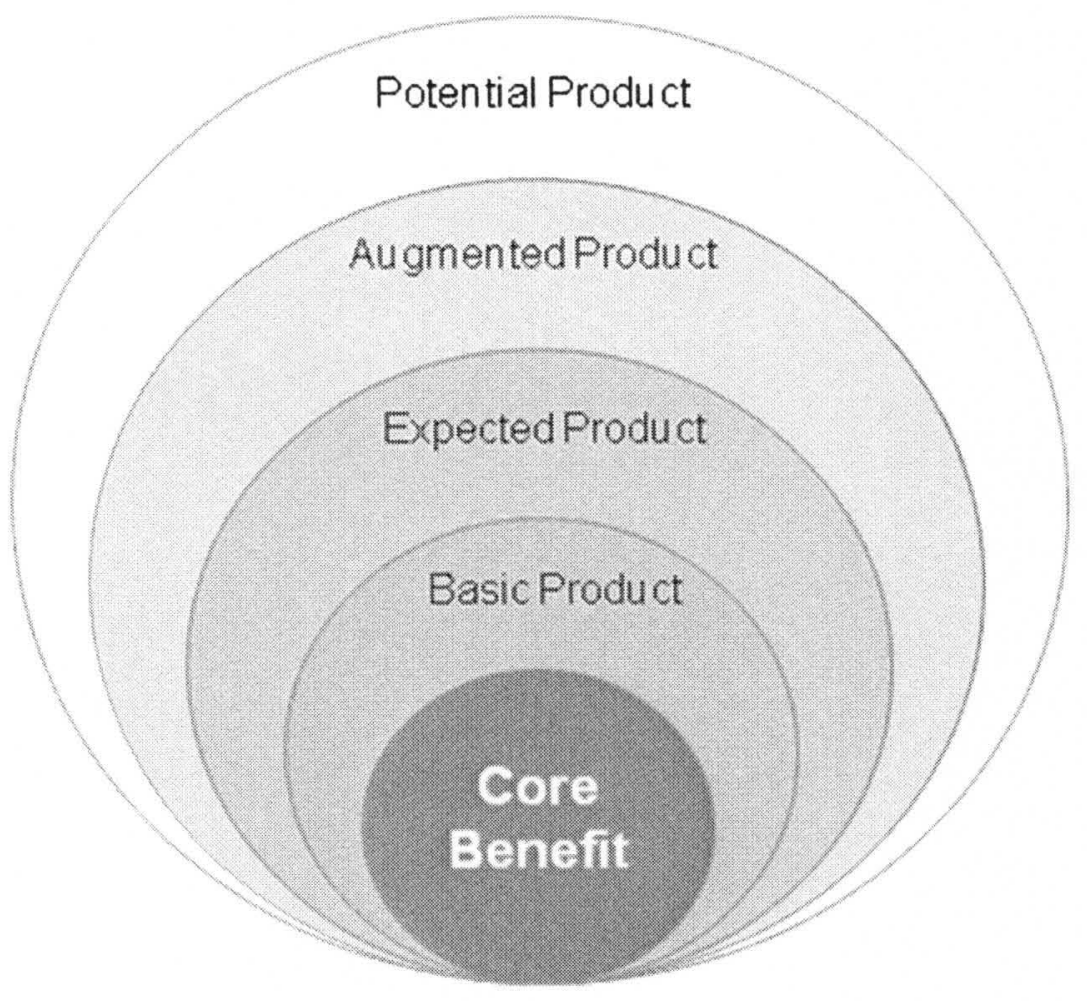

Figure 3. Five conceptual levels of a product (Kotler, Bliemel, 1999)

As Kotler explains, each of the five conceptual levels has to offer an additional customer value for the customer (Kotler, 1999). Using the example of a cinema these conceptual levels are described. The core value represents the fundamental expectation of the customer, in this case entertainment or relaxation. The generic product / basic product is the basic version of the product which includes the minimum requirements, in this case the screen, projector, film and chairs. The expected product includes characteristics that are normally expected by the customer based on experience, which could in a cinema 
mean a good picture and sound quality, comfortable seats, air-conditioning, snacks, etc. On the fourth level the expectations of the customer can be exceeded and therefore on this level the view of the marketing of inventions is decisive. The augmented product in the example of the cinema could include different elements, for example a special ambience (decoration, special seats, etc.), special services (online seat reservation, etc.) or special events. The fifth conceptual level includes per definition the potential product with every added value or product differentiation which are possible in the future. These conceptual levels of a product point out that at a certain point in time augmented parts of the product are perceived as normality by the customer. Therefore a dynamic innovation process is necessary to keep the product interesting for the customer.

The main target of the product innovation is to strengthen the position of the organization in the market. Product innovations are the answer to shorter life cycles of products, the changing needs of customers and the rapid technological change. It is proven by empirical research that the failure rate of product innovation is very high. Nieschlag quotes that the market success rate of product innovations is just as high as $3.7 \%$ (Nieschlag, 1997). Nevertheless organizations cannot waive product innovations. In the context of product differentiation they are crucial to the survival of an organization. Classic examples of successful product innovations are ball pens, the telephone and style counseling (Hartschen et al., 2009) 


\section{Process Innovation}

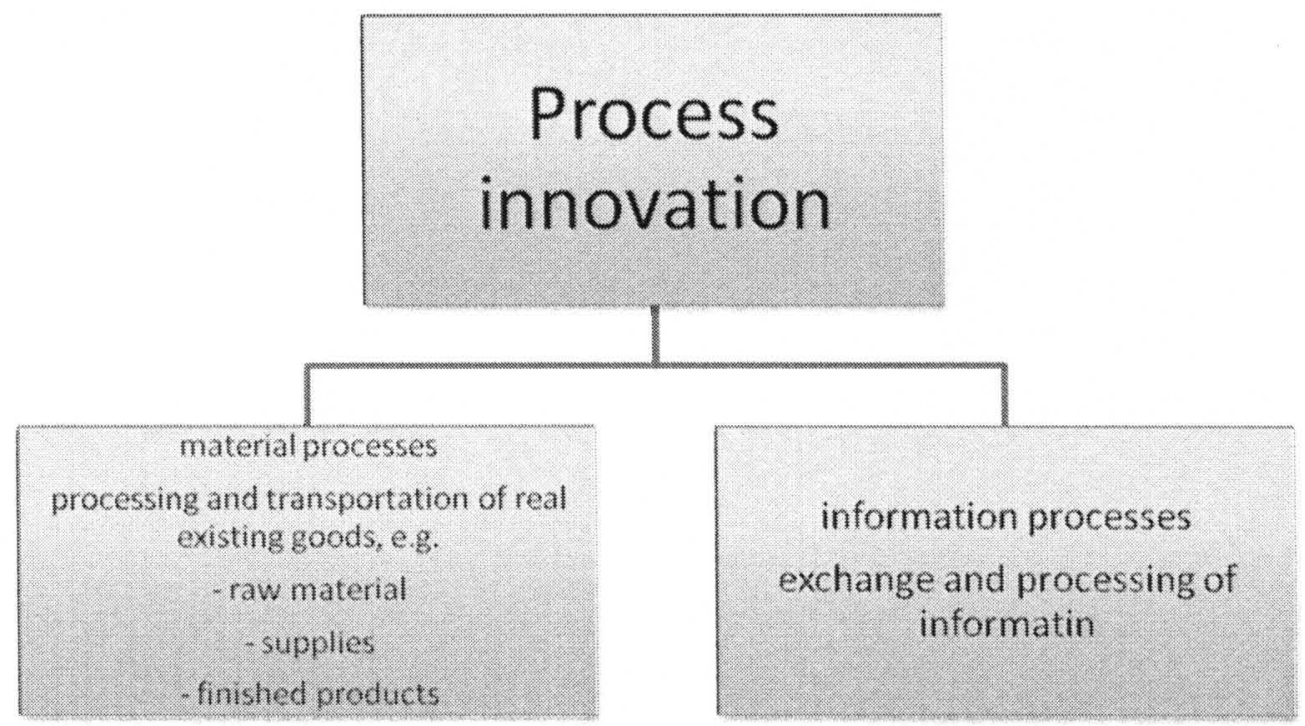

Figure 4. Classification of processes (Vahs, 2005)

Process innovations should improve the organization through enhancing efficiency and creativity. In a general understanding, processes describe the way in which things are done and in which order they are done in an organization in order to have an output that can be marketed. An process per definition starts with an order, at every step in the process line a kind of value is added and finally finishes with a predetermined output. The basic target of process innovations is the increase of productivity, which means the proportion between result and necessary time. Generally an organization tends to produce high quality goods at low costs which are directly positively affected by the process times. Other targets of process innovations could also be the reduction of needed resources (material, energy) or the increase of safety for the personnel or the machines. 
Classic examples for process innovations are assembly line work, just-in-time production, and digital theater tickets (Hartschen et al., 2009).

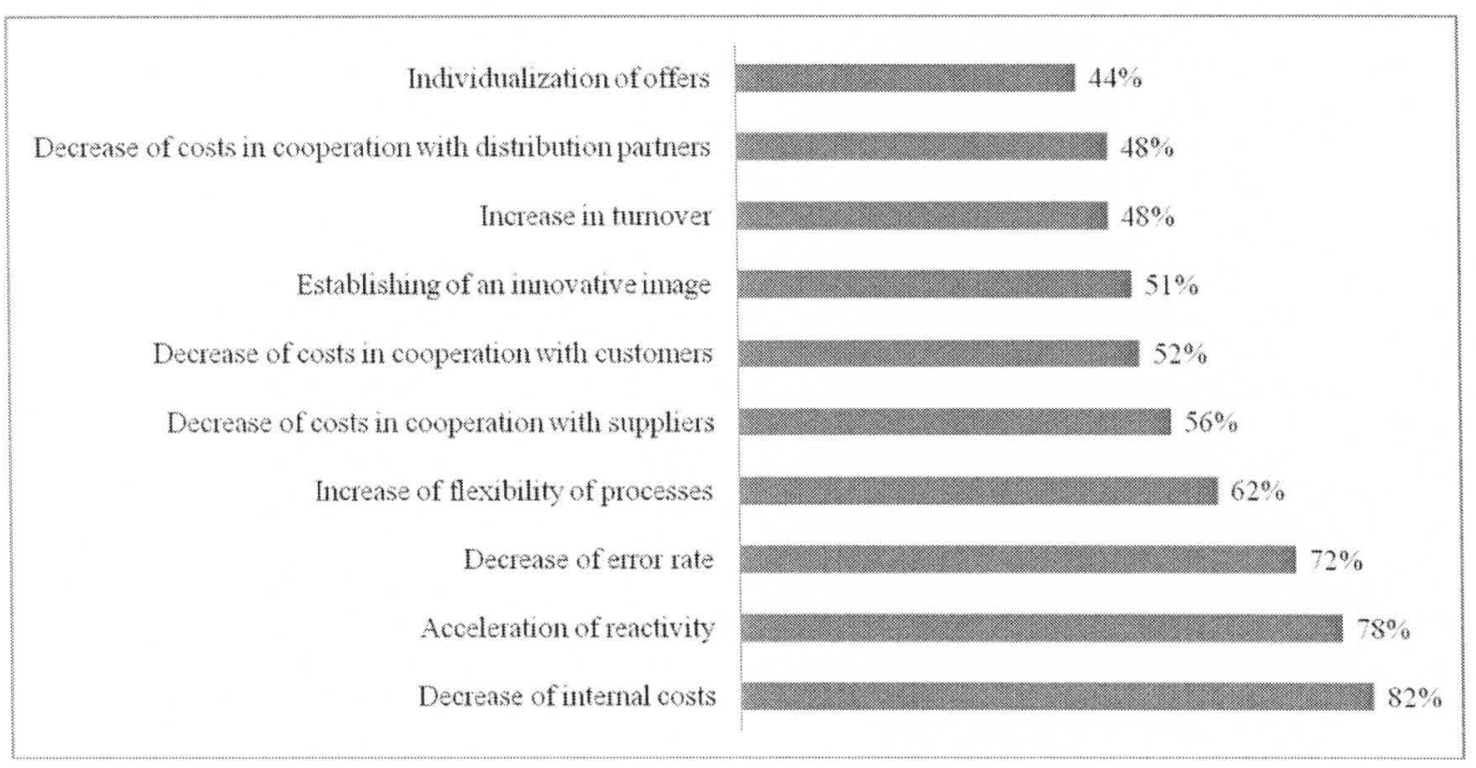

Figure 5. Aims of Process Innovations (Fink, 2005)

\section{Social Innovation}

Not only products and processes can be innovative. An increasing factor of importance concerns the field of personnel and the hierarchical structures in an organization. It is the desired status of an organization to be the preferred employer for innovative employees and to promote existing employees as "small entrepreneurs" in their department. The "cultural innovation" as it is sometimes also called refers to the employees and the management of an organization and helps improving the social standards. Those could be 
the safety at the working place, an increase of satisfaction, enhanced creativity etc. As one can see there is a strong connection between the social innovation and the other types of innovation and especially process and social innovations are very often hard to separate and very often they are the result of each other (Vahs, 2005). The main problem of social innovation is that it is very difficult to measure which is naturally much easier in a process innovation which e.g. saves time in a production line. It is very difficult to measure that the identification of the employees with the organization has increased and therefore has a positive effect on the overall result of the organization. Indicators for a positive influence of social innovations in an organization could be an increased employee satisfaction, a lower fluctuation rate or a lower incident rate. These data can be found out through a written questionnaire for the employees or with statistic methods.

Next to the human sector, the structure of an organization can be a social innovation. With the organizational innovation a positive effect can be realized both on "hard facts" like reducing costs, improved quality, etc., as well as on "soft facts" like increased satisfaction of personnel, higher level of creativity, etc (Vahs, 2005). Examples for social and cultural innovations are job rotation or the introduction of new management instruments like management by objectives, etc. (Hartschen et al., 2009).

\subsubsection{Differentiation by Degree of Novelty}

Until now it has not been answered how "new" an innovation is. In the view of a producing organization every product or process is innovative which is newly introduced into the organization. In the customer's view every product or service is innovative which 
he perceives as new. That means that the customer decides subjectively if there is an innovation or not, which means in his perspective he can only evaluate the output of an organization, not the internal processes (Garcia, Calantone 2002, Gerpott 1999, Hauschildt, Salomo 2007). Due to this fact a black and white view on innovations (innovative or not innovative) does not seem adequate anymore. Therefore multidimensional approaches to the description of the degree of innovations have gained more acceptance (Green et al., 1995). Those analyze the influence of an innovation on the change in an organization or in a market. Ceteris paribus the degree of innovation is higher the higher the change is. Therefore innovations can have impact on the following fields:

- Product Technology: Degree of novelty, potential of substitution, needed knowledge and experience

- Market area: new needs of existing customers, new customers, new sales channels

- Production Process: Requirements of machines, handling and service

- Purchase: Requirement of new (raw) materials

- Capital Demand: High costs for Research and Development, Marketing, etc.

- Formal organization: Necessity for new departments or spin-offs

- Informal Organization: Changes in the culture, the strategy or the management of an organization

To give an example in the following figure the dimensions "Market" and "Technology" are combined to give indications for the degree of novelty of innovations: 


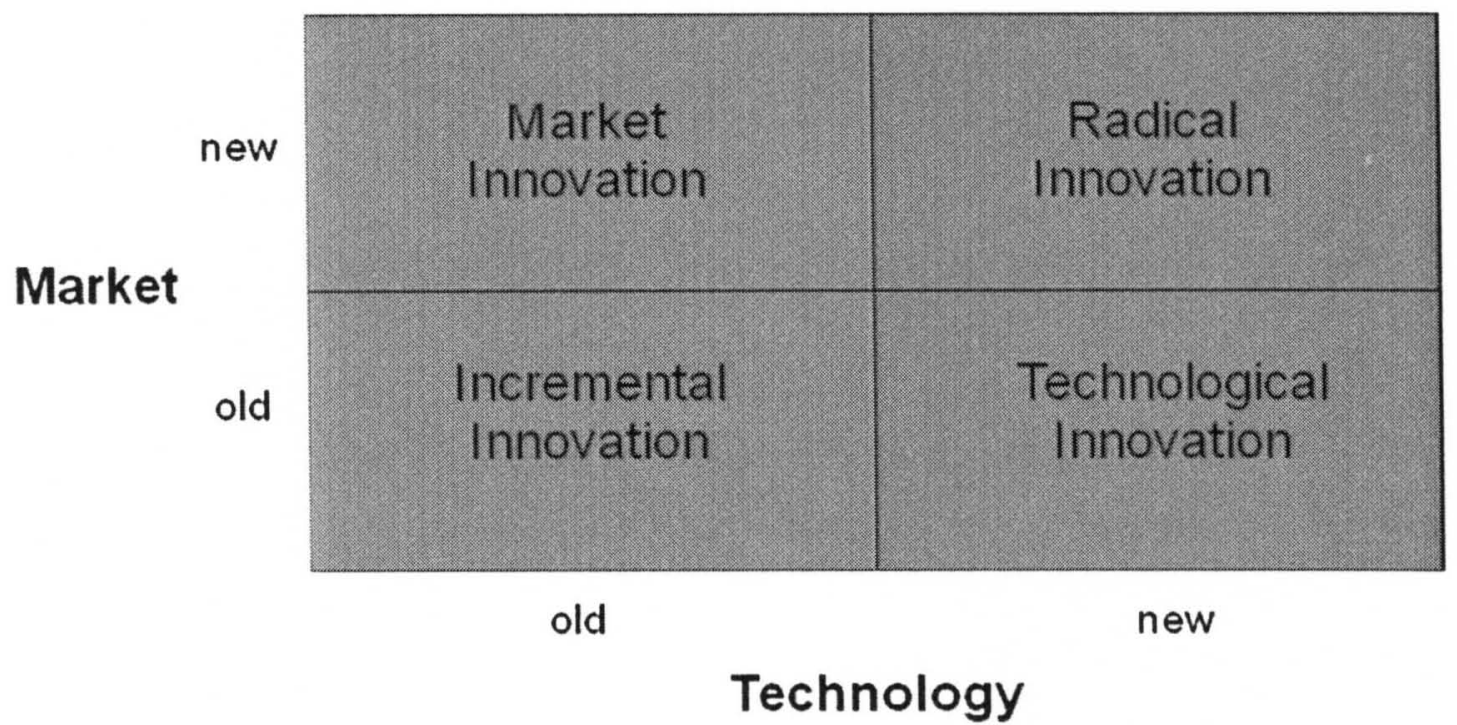

Figure 6. Degree of novelty (Reichwald, 2009)

If an organization uses an existing technology to serve an existing market with an existing product this is called an incremental innovation. In the view of the customer the product may have an added value but this mostly reduces itself on the factors price, quality, attributes or performance. Generally these incremental innovations only have a short term effect on the competitive situation of an organization. Very often changes through the continuous improvement process lead to incremental innovations. In comparison market innovations use an established technology to penetrate a new market. An example could be the boom of espresso machines for the private household. If an organization uses a new technology to serve an existing market, this is a technological innovation (Reichwald, 2009). The classic example in this context is the replacement of the Walkman with the Discman and today with the mp3-player. The last and most complex possibility is to explore new markets with a new technology which mostly displace old solutions. These radical innovations are completely new and highly 
economic solutions for the customer. They represent a change of paradigm for the customer and include attractive potential for the realization of new products or processes. They represent a quantum leap and are again a source for other innovations (e.g. incremental or technological innovations). A modern example of this radical or disruptive innovation is the mobile phone (Reichwald, 2009).

\subsubsection{Models of the Innovation Process}

Due to shorter life cycles of products and a growing and accelerating competition it is a must for organizations to regularly introduce new products to the market. As resources in an organization are generally limited a greater focus in the past years has been put on innovations management. Many attempts have been made to make the innovations management as efficient as possible and their outcome as profitable as possible.

Therefore many different models of the innovations process have been developed, both by scientific researchers and also by organizations for their own use. In literature there are uncountable different models for the innovations process (Examples are Cooper, 1983; Cooper, Kleinschmidt, 1990; Brockhoff, 1999; Pleschak, Sabisch, 1996; Vahs, Burmester, 1999). To give an overview only the basic and commonly accepted innovation processes and their adaptations over time are described in the following text.

Looking at the early models one finds different generations of process models (Cooper, 1994). The first generation of "Phase-Review-Processes" was developed in the 60's by the NASA and later on also used by the U.S. Military and different companies, e.g. Hewlett Packard. One main goal was the optimization of the cooperation between the 
organization and its suppliers. Therefore it is a process model which was developed and used as a management tool.

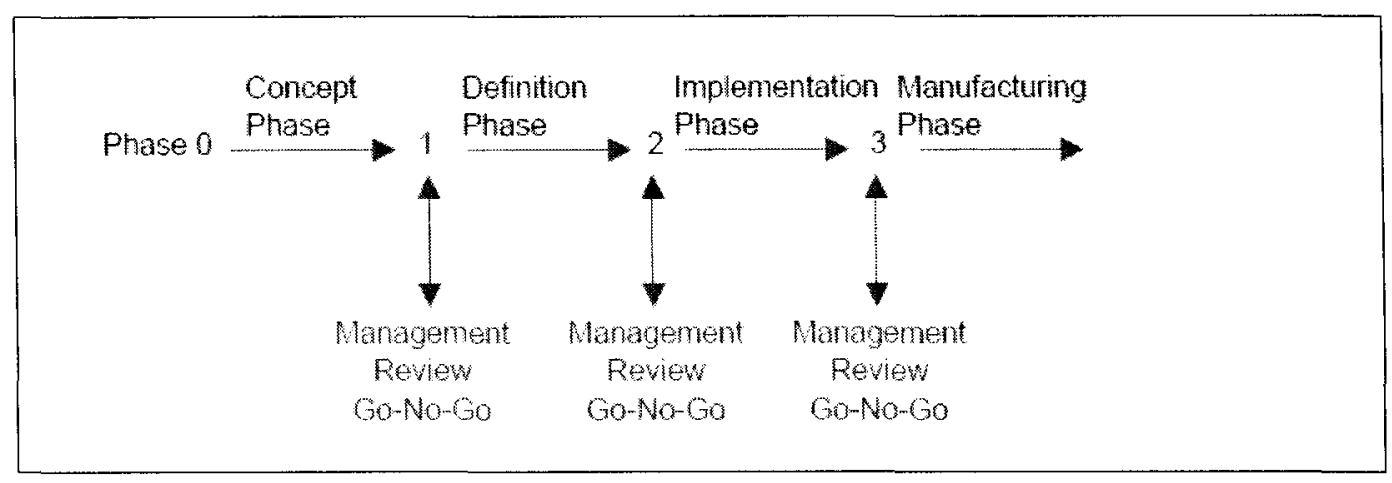

Figure 7. Phase-Review-Process (Hughes, Chafin, 1996)

As shown in figure 7 the innovation process is separated in phases. A Management Review is made after each phase which then decides if the project goes on or not. Therefore activities are standardized and the completion of different tasks is ensured. This approach can also have a negative effect if the project is stopped until the go-no-go decision and therefore the whole process is slowed down. Another disadvantage is the strong technology orientation as there are no marketing activities integrated. Furthermore not the whole innovation process from the idea to the market entry is displayed in this model.

Therefore this model was further developed especially by Cooper after studying the procedures of successful and not successful organizations. The usage of a "game plan" which means a standardized procedure within development projects was identified as a success factor (Cooper, 1994). Therefore Cooper and Kleinschmidt filtrate their experiences into a process model: 


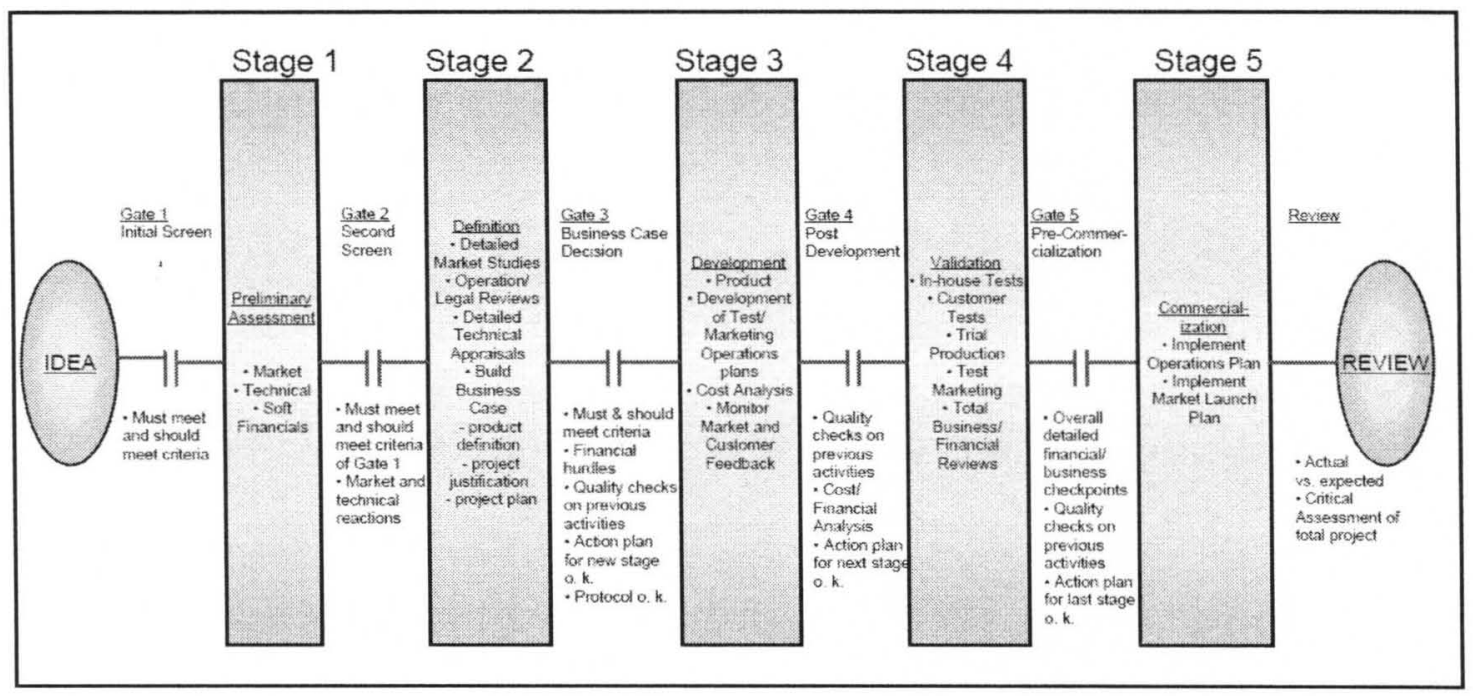

Figure 8. Stage-Gate-Process of the second Generation (Cooper, Kleinschmidt, 1990)

The Stage-Gate-Model is similar to the Phase-Review-Model but improves some of the mentioned disadvantages. It is an interdisciplinary process as it integrates all related functions like marketing and production. The decisions at the "Gates" are made by the different departments together following fixed Go / Kill criteria. The different phases do not anymore follow one by one but overlapping is possible which speeds up the whole innovation process. The main advantage of this model is the systematization of otherwise often chaotic processes of a development. The process is transparent and the team work is enhanced. This makes communication in the teams easier as well as communication with the management. In many big companies Stage-Gate-Processes are used as management tools, for example at IBM, 3M, General Motors or Northern Telecom (Cooper, Kleinschmidt, 1990; Cooper, Kleinschmidt, 1991; Whiteley et al., 1998). 
Another process model which is similar to the classification of the phases in Coopers' model was developed by Ulrich:

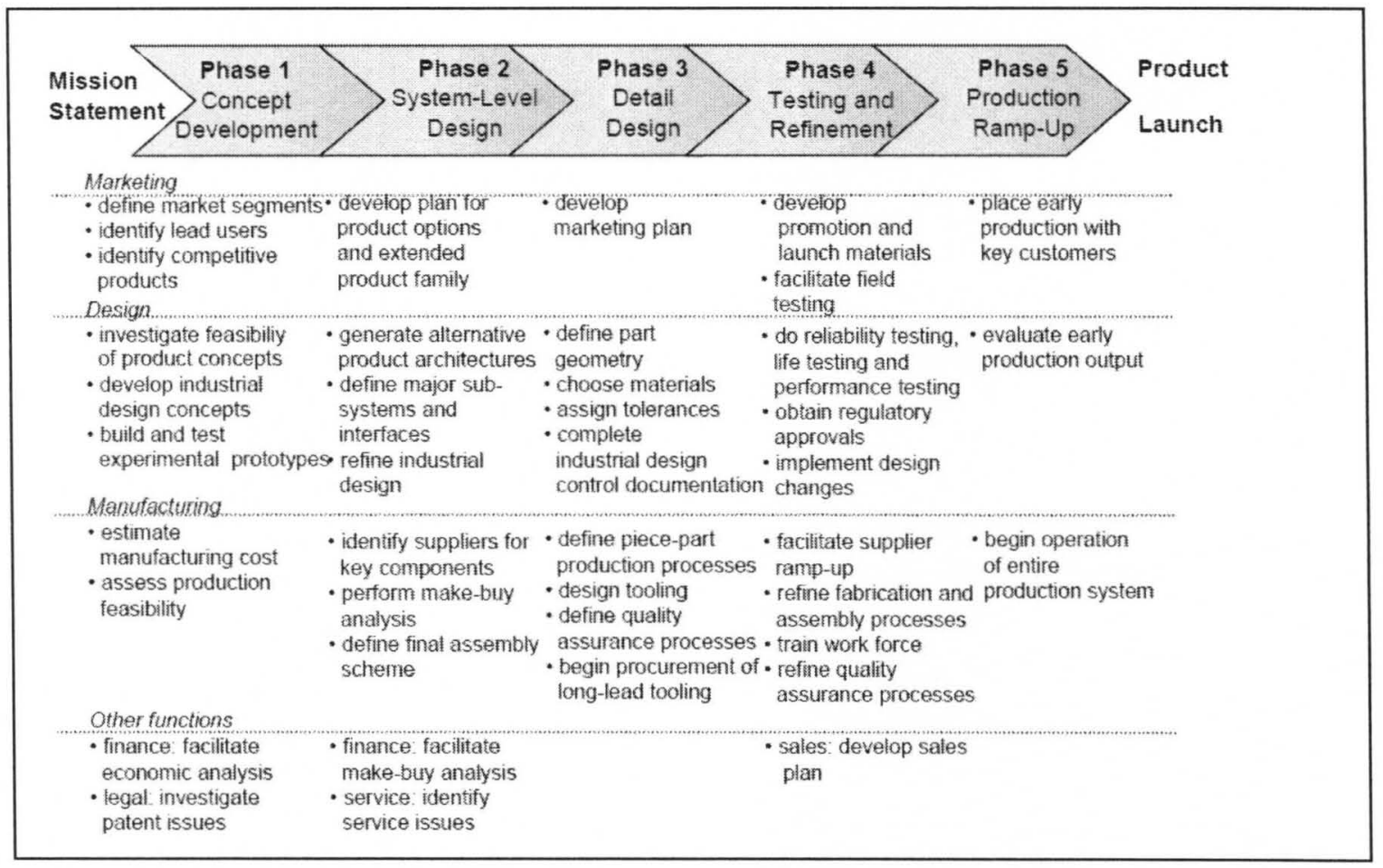

Figure 9: Process model by Ulrich and Eppinger (Ulrich, Eppinger, 1995)

Ulrich defines process models as effective management tools and offers his own process model as recommended proceeding (Ulrich, Eppinger, 1995). The different tasks of the different departments in the innovation process are described in detail and management tools are explained which can be used in the process. In the author's view the interesting idea of this model is the interdisciplinary approach which integrates all functions and hierarchies in all the phases of the innovation process.

In 1996 Cooper developed a new model for the phases of the innovation process. This and other normative Stage-Gate-Models of the third generation do not dictate the order of 
the former models in which sequential activities can slow down the process. The transition between the phases is smooth and different tasks are done in parallel in dependence to the actual project to speed up the innovation process again.

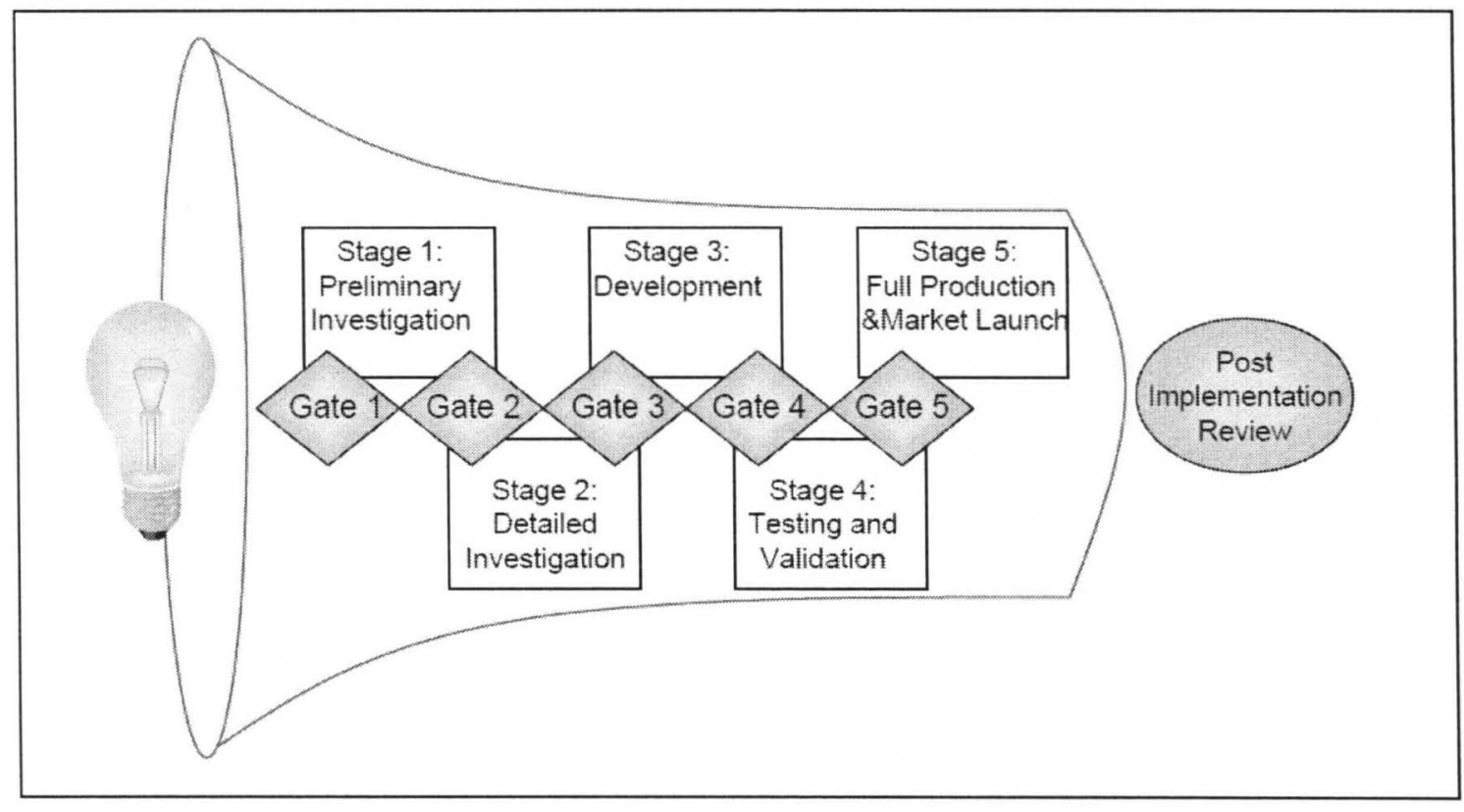

Figure 10. $3^{\text {rd }}$ Generation Stage-Gate-Process (Cooper, 1996)

In summary, one can post that in the model of the third generation is quite near to the use in reality because the implementation investment and coordination is not as high as in the former models. This assumption is also underlined by Crawford who points out that in reality the phases in the innovation process are overlapping and do not occur sequentially (Crawford, 1994). 


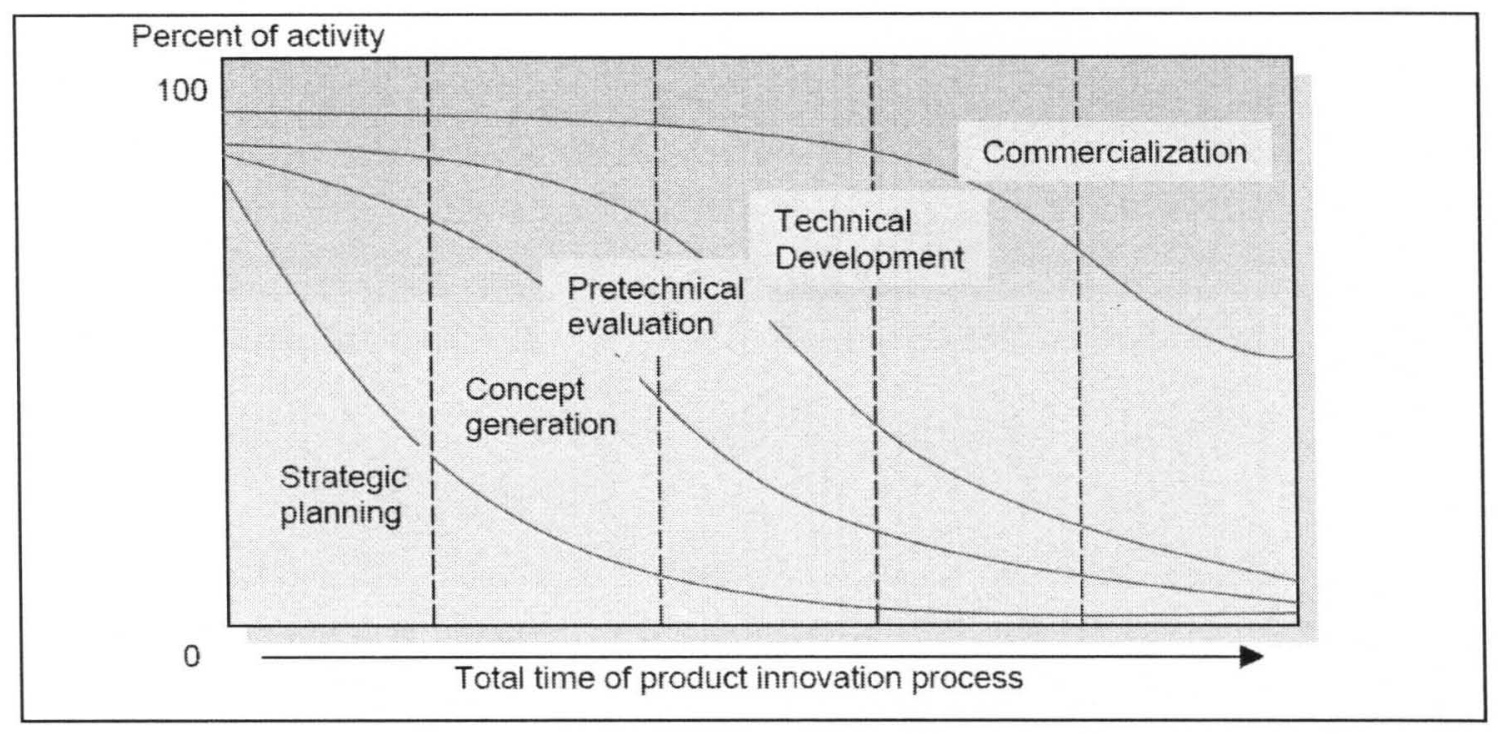

Figure 11. Simultaneous activities in the Innovation Process (Crawford, 1994)

Hughes developed in 1996 a different process model which again had as a major target to avoid slowing down the process through sequential tasks. He offers "Value Proposition Cycle" which was originally used in an organization which before had used the StageGate-Process (Hughes, Chafin, 1996).

According to Hughes the flexibility of the development should go far beyond the third generation Stage-Gate-Models. The efficiency and effectiveness of multifunctional project teams should be improved through continuous learning, reliability of information and the reaching of consensuses (Hughes, Chafin, 1996). The most important point is the continuous focus on how the value for the user or the customer can be enhanced. 


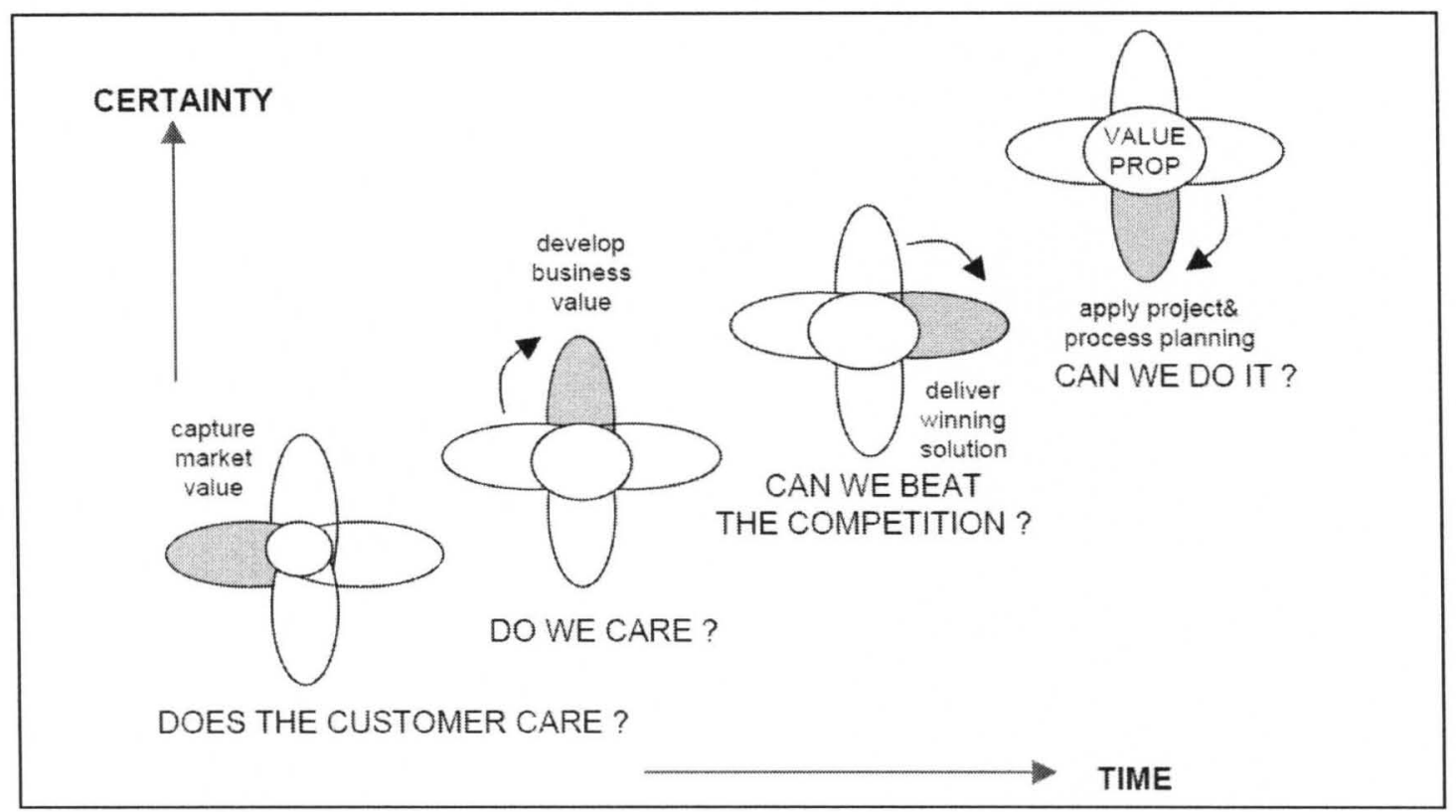

Figure 12. Value Proposition Cycle (reprinted from Hughes, Chafin, 1996)

The "Value Proposition Cycle" consists of four iterative loops which identify the market value, the business value, the better solution in comparison to the competition and planning of the project / process. The growing value while repeating the questions is represented by the size of the ellipse in the centre. The continuous running through the loops guarantees the quick reaction of the team on changes in the market. In the view of Hughes this point was missing in all Stage-Gate-models of Cooper.

\subsubsection{Phases in the Innovation process}

As pointed out in the last chapter many different models exist to describe the innovation process. In order to focus on the customer orientation in the early stages in the innovation 
process it is important to define a simple innovation process which is applicable to new products, processes and services. Therefore the author decided to use a simplified model to describe the innovation process in five phases by Herstatt and Verworn (Herstatt, Verworn, 2003).

\begin{tabular}{|c|c|c|c|c|}
\hline Phase I & Phase II & Phase III & Phase IV & Phase V \\
\hline $\begin{array}{c}\text { Generating ldeas and } \\
\text { Evaluation }\end{array}$ & $\begin{array}{l}\text { Concept, product } \\
\text { planning }\end{array}$ & $\begin{array}{c}\text { Development, } \\
\text { Designing }\end{array}$ & $\begin{array}{l}\text { Prototyping. } \\
\text { Testing }\end{array}$ & $\begin{array}{c}\text { Production. } \\
\text { Market entry and } \\
\text { Market } \\
\text { Penetration }\end{array}$ \\
\hline
\end{tabular}

Figure 13. Model of Innovation Process (Herstatt, Verworn 2003)

\section{Phase I - Generating Ideas and Evaluation}

In the first phase of the innovation process, ideas are generated. These ideas can be generated by employees, customers or suppliers, or the impulse can originate from the organization as the generating of ideas is focused on customers, technologies or the optimization of costs. To generate these ideas one can use techniques for creativity or workshops with or without people from outside the organizations. Other common methods for generating ideas are

- Company suggestion plan

- Interpretation of complaints

- Analysis of competition

- Market research, trend analysis 
- Trade shows

These mentioned methods for generating ideas for new products in an organization are generally limited in their output. Therefore more complex methods have been developed like the Empathic Design Method or the Lead User Method which will be described in more detail later in this thesis.

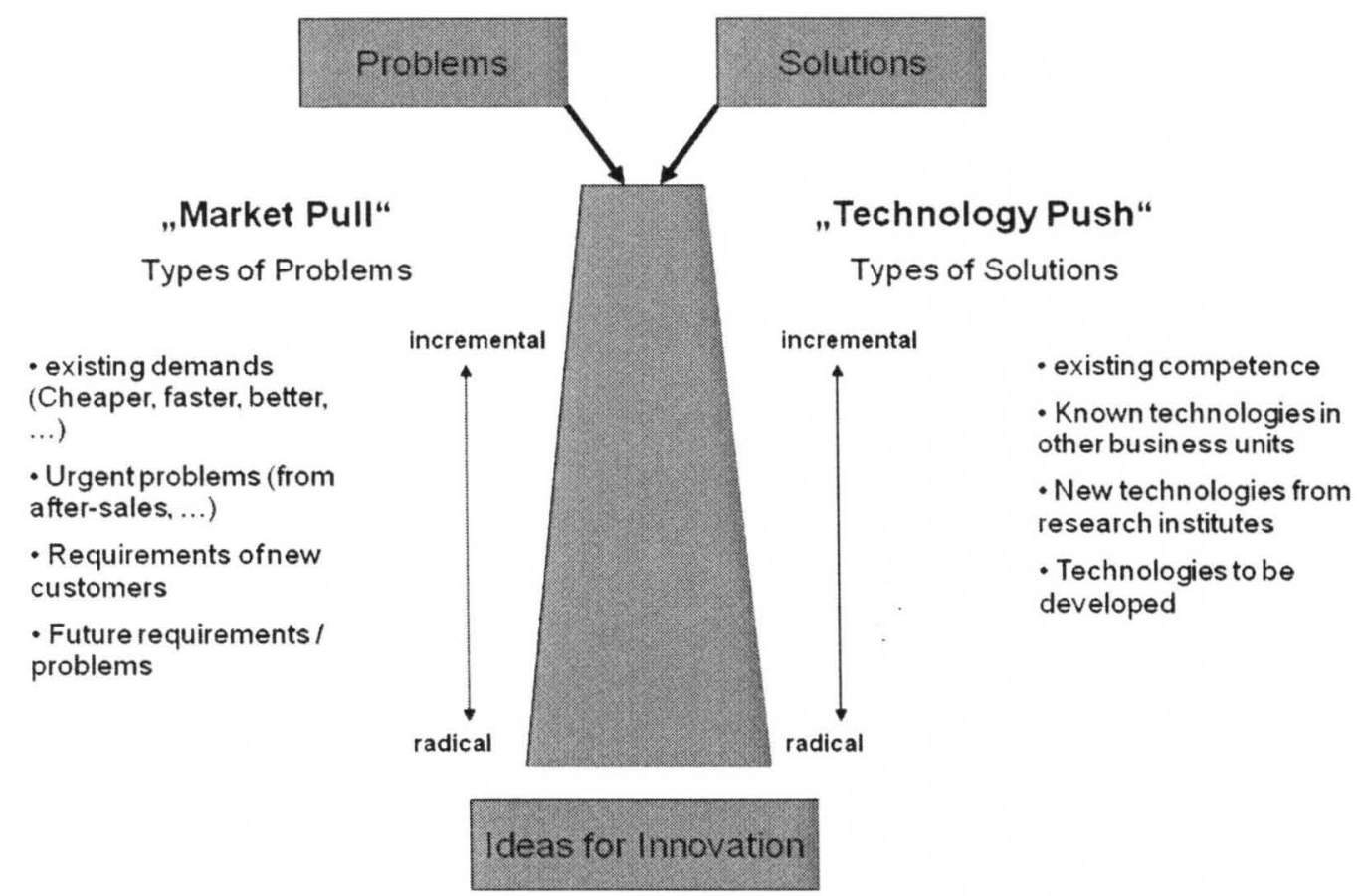

Figure 14. Ideas for innovations as a combination of problems and solutions (Kobe, 2003)

After having generated a number of ideas those ideas are evaluated concerning their attractivity and their risk. They are compared to existing projects and if necessary the project portfolio of an organization can be adjusted. 


\section{Phase II - Concept and Product Planning}

In the second phase concepts for possible products are developed. This includes the specification of the possible product, e.g. what features it has, what kind of variations can be possible, etc. Based on these concepts also a first planning of production has to be made. This includes (depending on the individual product) the number of products produced, cost of product, needed investments e.g. in machines, costs of the overall project, timing of market entry, etc. Furthermore the possible market for the product has to be analyzed. A very important point in this context is to find out how big the acceptance of possible customers for the new product really is. This again leads to information about competitors or alternative products / solutions. Generally at that point the internal and external information are brought together to scenarios. For evaluating the economic situation and to decide about if or if not the project should be continued, product price / quantity combinations are made and put together in a "best case", "worst case" and "realistic case" scenario.

\section{Phase III - Development and Designing}

In the third phase the product itself is designed and developed. It is absolutely necessary that the development accords to the specifications and guidelines in phase II. Interdisciplinary teams are formed for the development project to cover all important aspects of the project and therefore of the future product (Herstatt et al., 2003) Very often companies work with industrial designs and samples which are regularly reviewed 
concerning their design, functionality, cost structure, fit to existing production possibilities, etc.

\section{Phase IV - Prototyping and Testing}

In the fourth phase prototypes of the products are produced. Those are tested in the company. In a second step these prototypes are also tested "in the market", which means that they are tested by selected customers. This is important to test aspects like handling, durability, acceptance, etc. before the final product is designed. These insights again are collected and brought together with the internal information, and the final design of the product is developed. For this final product (mass-) production facilities are prepared and necessary investments are made.

\section{Phase V - Production, Market Entry and Market Penetration}

In the sixth phase of the innovation process the production of the new product or the new production line starts. The market entry is prepared by a marketing concept which includes all aspects like price, promotion, distribution channels, packaging, training of sales people, etc. This marketing plan of course relies also on information which was gathered in the phases before. This is a good example why the project teams should be interdisciplinary because in the marketing plan all the information of the customer and the market have to be considered and a special focus on the unique selling point of the new product has to be made. After a successful production and quality testing of the 
product it can enter the market. Inside the company the existing portfolio of products has to be checked if the product mix is still acceptable or if, regarding the new product, any other / old product has to be taken out of the portfolio. Another important insight at this point in time is that the need of innovation for the company does not stop here. It is very important to start thinking of improvements of the new product for the future and to restart the innovation process to ensure a constant flow of innovation / new products for the organization.

2.1.7. Definition of the Early Phases in the Innovation Process

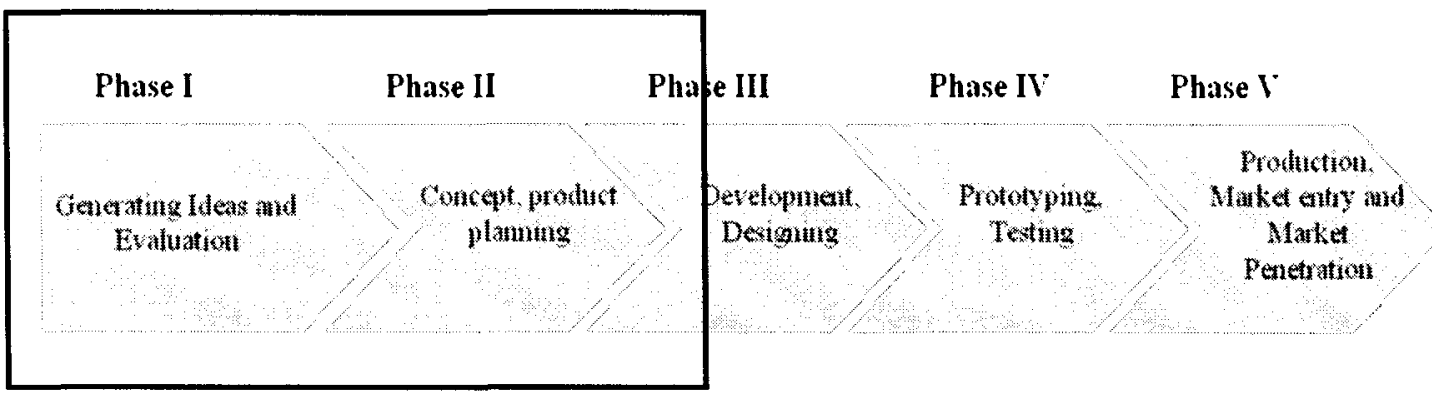

Figure 15. Early Phases in the Innovation Process (Herstatt, Verworn, 2003)

In literature there are many different terms for the pre-phases in the development process for new products. Terms used are e.g. "pre-development", "up-front-activities" or very commonly used "fuzzy front end" (Khurana, Rosenthal 1998). Despite all differences in terminology in nearly all of the models of the innovation process the early stages mean the actions in the time from the generation of ideas to the point when these ideas are 
concretized into a project plan. That means that the early stages mean all activities before the so called "start of the project" when the project is equipped with resources in the organization. In literature this point in time is very often called "Money Gate" (Nobelius, Trygg, 2002; Khurana, Rosenthal 1998). Following this definition the so called "back end" of the innovation process includes all other steps in the innovation process, which include for example the development of the product, the prototyping of the product up to the market entry of the product.This divides the innovation process in two parts, the "front end" and the "back end".

Even if the models of the innovation process are different in literature this is what most models and theoretical approaches have in common (e.g. Dorbandt et al., 1990; Gaiser, 1991; Moenaert et al., 1990). Looking at the simplified model of Herstatt and Verworn the early stages of the innovation process include the phases I and II. In this model these two phases include activities like generating ideas and the evaluation of ideas and their fit to the strategy of the organization. Furthermore, phase II includes the conceptual phase when a project plan is set up after e.g. a market analysis and a further concept of the product including for example cost-planning, timing, necessary investments, etc. Following the above mentioned commonly used definition this is before the "money gate". This does not mean that the phases I and II do not cost money or do not have to be budgeted by an organization but at this point of time the costs are planned and afterwards spent specifically for the new / planned product. At this point of time the decision of further working on the product is made and from different possibilities / ideas one is chosen and the organization will follow this project whereas other ideas will not be followed any further and end after phase II. 
In the view of the author this is the most important decision in the innovation process as at this point of time the organization decides about future products and, what is equally important, for which projects the naturally limited resources (money, people, etc.) of the organization are used. Having chosen the wrong project(s) at this point of time can generate substantial problems for the organization in the future when the life cycles of existing products come to an end and the following products do not meet the needs of the market and therefore do not re-earn the money spent and contribute to the earnings of the organization. This is what makes the management of the early stages in the innovation process so important but also difficult, as it can in a high degree decide about the future of an organization.

\subsubsection{Characteristics of the Early Phases in the Innovation Process}

The "front end" is also called "fuzzy front end" because the activities in these phases of the innovation process are relatively unstructured and dynamic. Generally the degree of documentation is not very high and internal processes and responsibilities are not clearly defined (Herstatt, Verworn, 2003). As already mentioned the uncertainty regarding the market and the technology are at this point of time at their highest level compared to the later phases of the innovation process:

\section{Uncertainty of the Market}

Very often, specified customer needs and demands do not exist due to the fact that customer needs are very often only latent. Therefore it is complex to estimate the degree of acceptance of a future product. Furthermore it is tricky for the organization to estimate 
the usage of the new product by the (future) customer especially in combination with other products or technologies. Especially regarding the dynamic markets this can be very challenging for the organization as other new products or solutions can reduce the usage and therefore the success of the newly developed product in the future.

\section{Uncertainty of Technology}

Due to the mentioned lack of specified future customer needs, typically technological specifications for the future cannot be clearly defined. Therefore the potential acceptance of a new technology or an alternative combination of technologies cannot be rated regarding the acceptance by the customer. Another point is the uncertainty of the feasibility which means at the beginning of the innovation project it can be in a high degree uncertain if the new technology will actually work out or stay in an acceptable cost frame, etc. That means that even if the estimated acceptance of a new product / a new technology will be very high and therefore the project will go through the "money gate", it still can be quite uncertain if the technical development will finally meet the expectations.

Very often the uncertainty of the market and the technology are highly related. In the view of the author a good theoretical example out of the past could be the further development of the portable CD-Player, e.g. regarding the runtime of its battery. Theoretically, even if the development of the new battery had been highly successful, it would probably not have been a market success due to the development and market entry of MP3-Players. These MP3-Players offer the possibility to have much more music 
portable than only one compact disc and even on a much smaller format. Therefore even if the battery of the portable CD-Player had been much better in comparison to the MP3Player, the overall technology had changed and the newly developed battery would not be an improvement accepted by the customer and therefore would not be a market success and would not contribute to the (re-) earnings of the organization. In the author's view this example makes it quite clear how difficult it is for organizations to decide for future products regarding the fast changing demands in today's dynamic markets.

Another characteristic of the early stages in the innovation process is the creativity which is needed for generating ideas and to develop them further. It is an ongoing discussion about the amount of freedom needed for creativity and how an organization provides an atmosphere encouraging innovation. Regarding the innovation process, in literature very often a looser structure is requested in the early stages of the innovation process whereas a more strict and planned structure in the later phases of the innovation process is necessary (Johne, 1984). Therefore the methods of developing ideas at the beginning of the innovation process are generally more open but not necessarily unstructured. In the following text several methods for the beginning of the innovation process are described. They all have in common that they have a high degree of customer orientation right at the very start of the innovation process which also means the direct or indirect integration of customers in the process of generating ideas. 
2.2. Methods for Customer Orientation in the Early Stages of the Innovation process

As there are many methods and approaches for the focus on customers' needs / perception or even the integration of customers in the early phases of the innovation process, the author focuses in the following chapters on selected methods.

\subsubsection{Models for Positioning}

To generate first ideas for new products, models for positioning can be used. These models sort existing products into ranges of perception in the view of the customer. The axes stand for product features / attributes which are decisive for the customer's buying decision (Urban, Hauser, 1993).

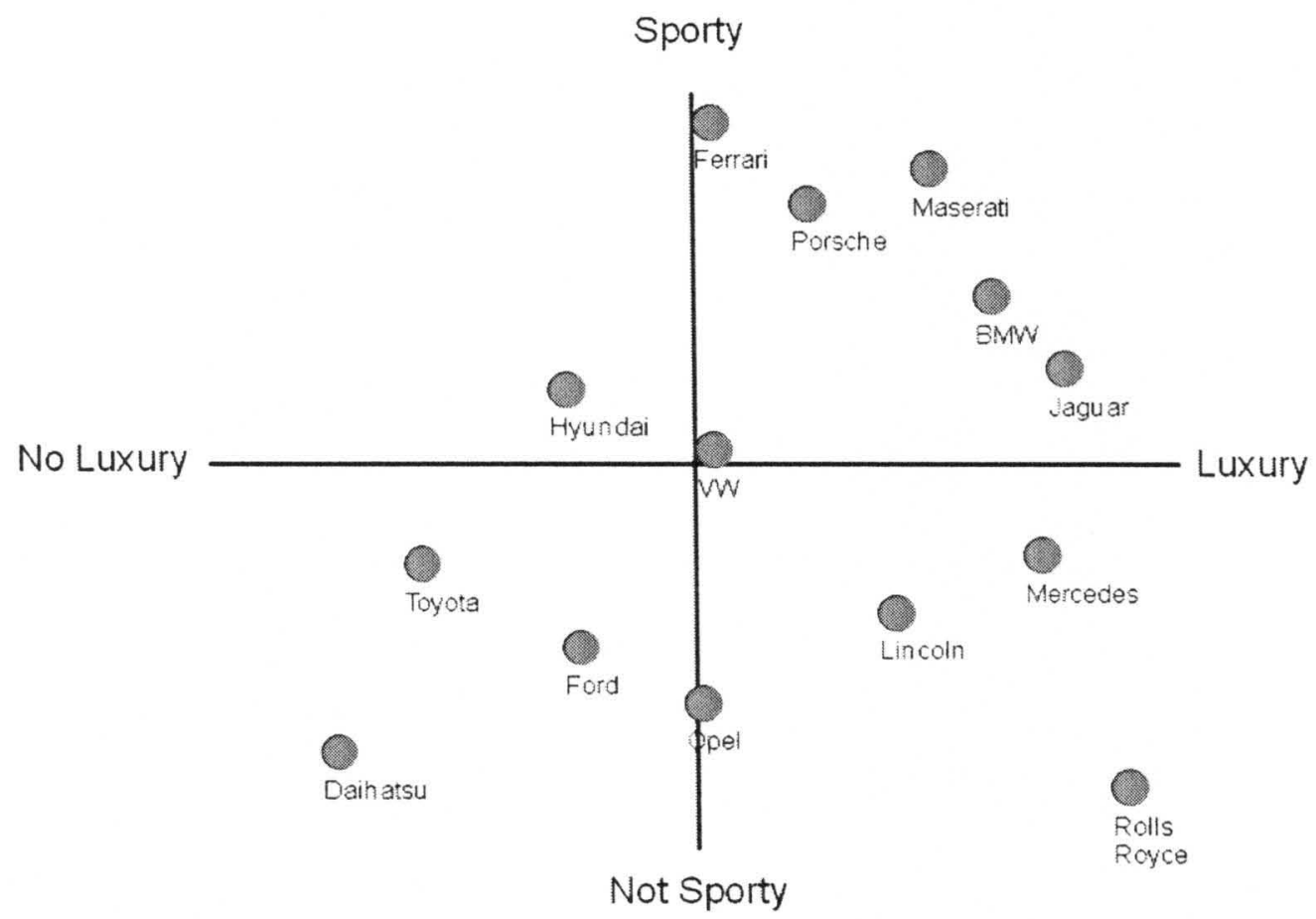

Figure 16. Positioning of car brands in perception matrix (The author's illustration) 
Figure 16 is an example of a two-dimensional product matrix for the car market. Commonly known car brands are listed following the two product attributes "sportiness" and "luxury". Of course many other attributes could be possible depending on the field of interest of the organization which is searching for new ideas or products.

Looking at the matrix and therefore at the existing products on the market first indications for innovations can be found. Especially areas in the matrix which are not occupied by existing products can be fields of interest for an organization. Furthermore, organizations which are not satisfied with the perception of their products in the market by the customer can define procedures and innovation projects to change the position of the organization or its products in the market. 


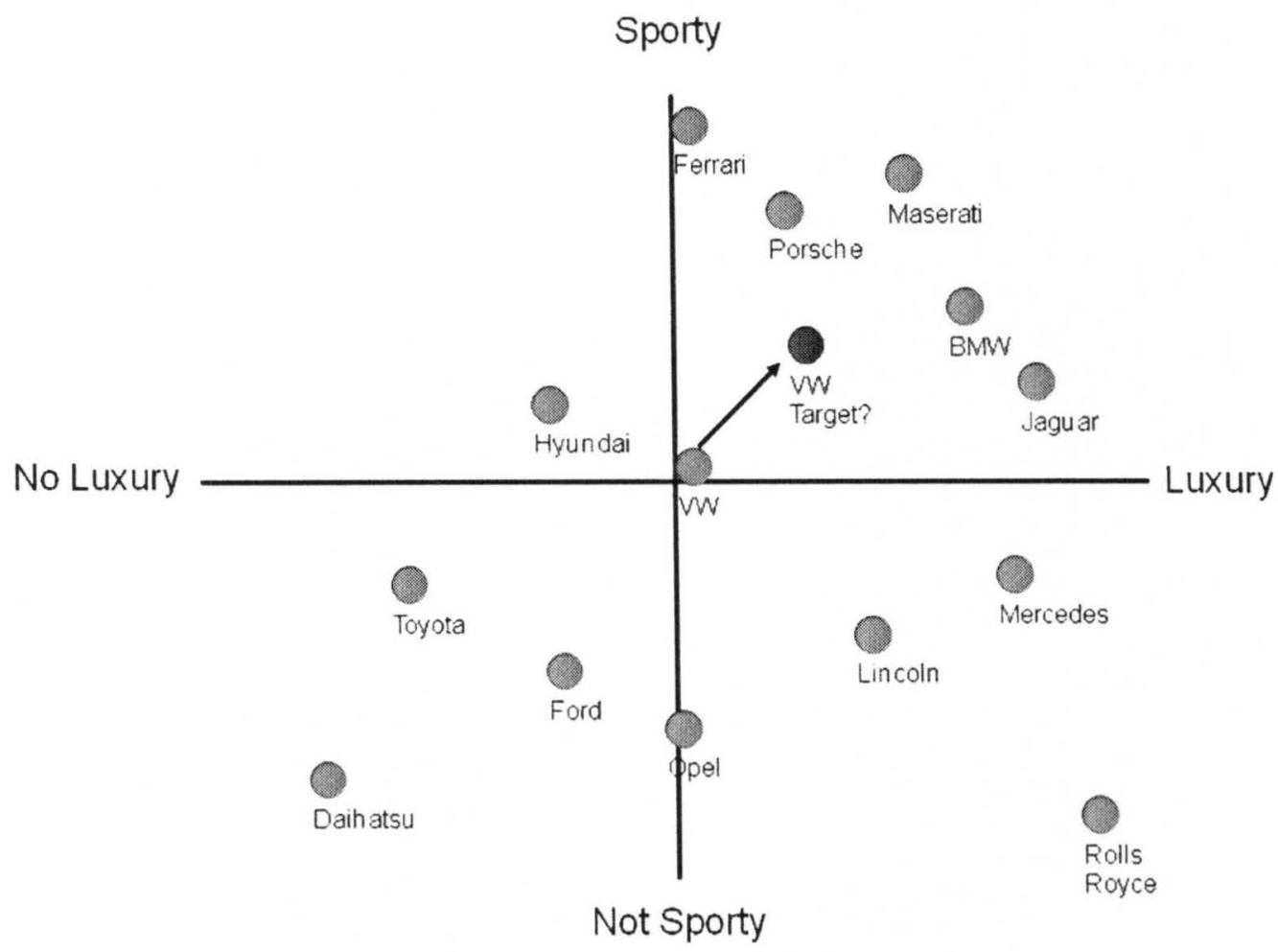

Figure 17. Possible desired change of position of Volkswagen (The author's illustration)

Looking again at the market of car brands in Figure 17, looking for example through the glasses of Volkswagen they could not be satisfied with being not clearly positioned in the eyes of the customer (not sporty, no luxury, etc.). Their goal could be to move in the perception of the customer to a more luxury and sporty image. Therefore innovation projects can be started which have the overall goal to develop products which support the mentioned shift.

Even completely blank fields can be discovered, in the given example of the car brands the combination of sporty and not luxury. That could also give new insights about market niches or possible new products. 


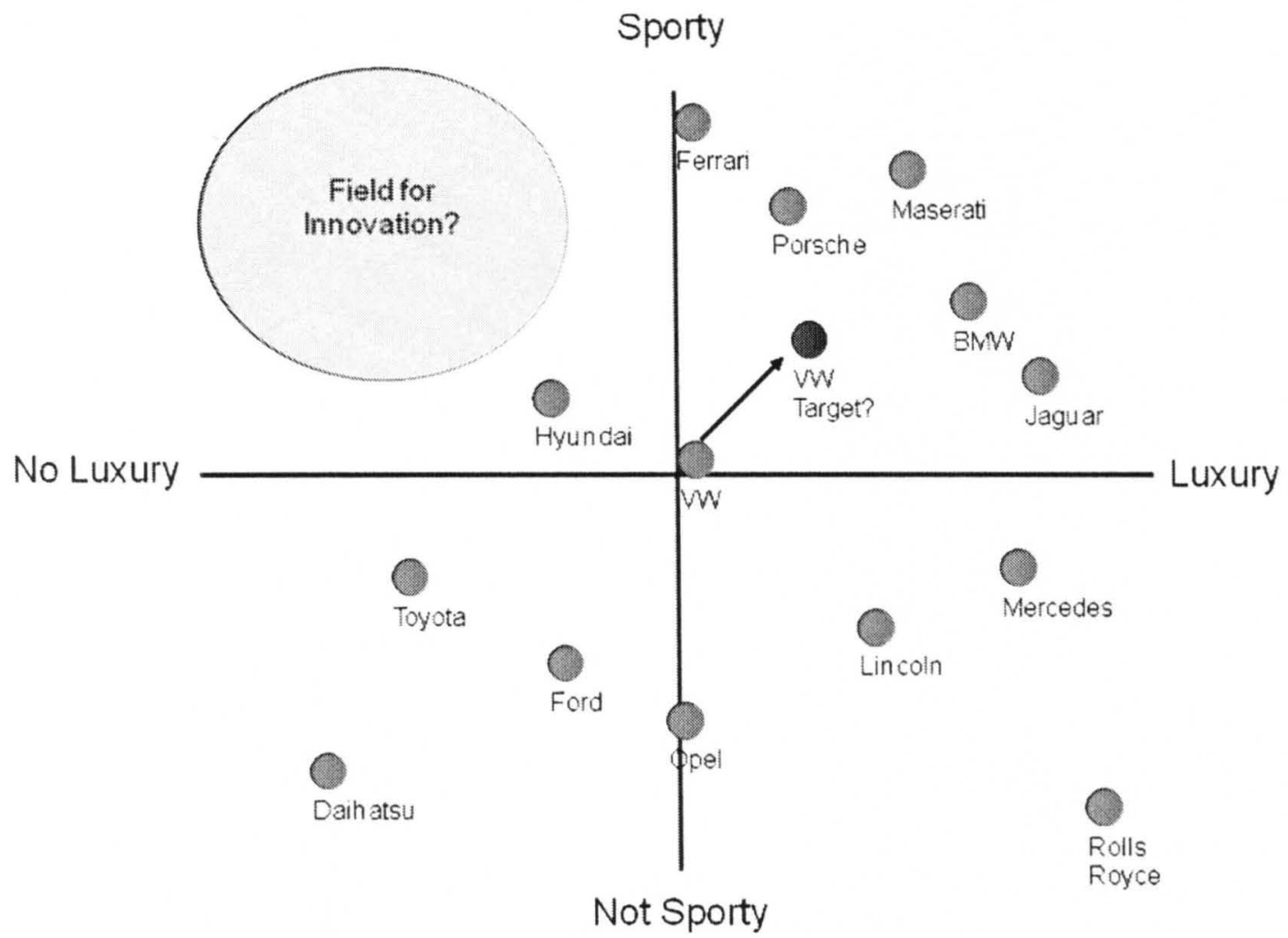

Figure 18: Discovering market niches (The author's illustration)

The deciding question in the models for positioning is to find the right attributes for the axes of the matrix. Therefore there are two alternative approaches: factor analysis and multidimensional scaling.

Using factor analysis, first of all existing products (also services and other offers in the market are possible) are evaluated by a number of customers regarding many different attributes of the products. Using the results of this evaluation one searches for attributes which correlate in the perception of the customer and to bundle them to a limited number of factors. If the result of this approach is only a number of two or three factors, it is possible to draw them into a two or three dimensional matrix (axes). The values of the 
factors have to be computed and they represent the coordinates in the matrix of perception. The advantage of the factor analysis is the relatively easy and quick possibility to interpret the results and that in comparison to other techniques only little interventions of the researcher are necessary. On the other hand it can be problematic to use this approach in new markets in which the relevant product attributes are not commonly known and therefore the perception of the customer is not reliable or even not yet existing (Lüthje, 2003).

Multidimensional scaling also leads to a positioning of existing products in a matrix of perception. In comparison to factor analysis no estimation of product attributes runs into the analysis. In spite of that customers are asked to evaluate the similarity of different products. In the approach of multidimensional scaling these judgments are transformed into distances in the matrix of product perception. The more similar two products are the closer to each other, they are or the other way round: the less similar two products are the larger the distance between these two products is. At the beginning the axes of the two or three dimensional matrix are not defined. It is in the decision of the researchers and the managers of the researching organization to define the attributes which represent the axes in the matrix. This is also the main disadvantage of this approach as it leaves relatively large space of interventions of the researches. This quite often leads to problems regarding reliability and validity. On the other hand the advantage of this approach is that in comparison to the factor analysis no pre-information of the relevant product attributes is necessary, which makes this approach more applicable for new markets (Lüthje, 2003). 


\subsubsection{Empathic Design}

The basic idea behind the approach of empathic design is that customers very often are not aware of their needs of new products. Very often customers have gotten used to the usage of existing products and they are not aware of existing problems in the use of these products. Very often customers develop implicit strategies to solve the existing problems. This way the customer does not become aware of the existing problem anymore as he has solved the problem for himself with his own strategy. To give an example, very often software users cannot right away name many problems of usage with the existing software. This changes rapidly when the customers are monitored when using the software. As a rule many user mistakes and "self-made" solutions can be recognized, which can give hints for improving the existing product or even the development of new products (Leonard, Rayport, 1997). In the opinion of Leonard and Rayport it is highly productive to observe customers when using products. This idea of research is not new and has gained a lot of acceptance in market research generally (Berekoven, Eckert, Ellenrieder, 1993). But still today most of the methods observe the customer in unnatural surroundings. Generally customers are brought to product clinics or research laboratories which are unnatural surroundings for them. This has a strong impact on how they use the products, and as a result much information about the "real-life-usage" stays unrecognized. For example it is not possible to find information about alternative usage of products in this environment. When a product manager for cooking oil in an aerosol observed his neighbor spraying the oil on the bottom side of his lawn mower, he found a new field of application for the existing product, or, put in other words, a niche for a new product. The cooking oil prevented, in an environment friendly way, that the cut grass 
would stick on the bottom side of the lawn mower. This use of the cooking oil would not have been discovered if the customer would have been observed in a testing kitchen (Lüthje, 2003). Furthermore, in artificial situations of usage, no interaction between the product of interest and the environment of usage of the customer can be found.

To give another example, Lüthje refers to the company Intuit, which is a producer of finance software. They tried to gain better research results by observing customers when using their software at their own computers. This way they found out which other programs were used simultaneously to the software of Intuit and which documents (electronic or paper) were used when working with the software. This led to a number of hints for the design of functions of import and to interfaces to other programs (Lüthje, 2003).

\subsubsection{Emphatic Design Process}

The Empathic Design process can be divided in four steps:

\begin{tabular}{cccc} 
Step I & Step II & Step III & Step IV \\
Observation & Collection of Data Analystis and & Development \\
& & Interpretation & of first \\
\hline & & of Data & Solutions
\end{tabular}

Figure 19: Phases of Emphatic Design Process (The author's illustration) 
Step I - Observation

The first step is to clearly define who should be observed. One can decide between different groups of customers or users or the customers of customers. This depends on the company which is doing the observation, if it is for example a producer or a sales organization. Also observing non-customers is another possibility to find out how they use products of other companies or what habits they have doing a special task of interest for the observing organization.

After having decided who should be observed, the next question is who should actually do the observation. Depending on the educational and professional background of the observing person the results can be completely different. A technical product developer may gain insights about possible improvements by e.g. changing the form of the product, whereas a marketing specialist would e.g. observe how packaging and design have an impact on the user or an ergonomist would strongly focus on how the product is used by the person and if the usage looks handy or not. Therefore even if those people were observing the same situation they would come back with different but nevertheless interesting information from different points of view. In the view of Leonard and Rayport at least one person of the observation team should have experience and further skills in observation (Leonard, Rayport, 1997). As not many organizations have a pool of skilled observers they often outsource the observation to specialized organizations or create a team of their own people and specialists from outside. Generally members of empathic design groups should have the following characteristics: open-mindedness, observational skills and curiosity (Leonard, Rayport, 1997). 
The selection of the observed people directly relates to the third point that has to be defined in advance, which is the decision as to which behavior should be observed. One possibility is to observe people when they are using the product of interest in their daily life, e.g. when they are cooking, washing, working, at the location where they usually do that, e.g. at their home. The advantage is that this generates real-life information about the consumers' habits. On the other hand not many people can handle the situation "normally" when someone is looking over their shoulder or following their daily routine. The opposite of this approach is to force the test person to do something and watch them fulfilling the task. This generally leads to unnatural behavior of the consumers and it depends on the goals of the observation if the outcome is sufficient. The third possibility is to observe people without them knowing that they are being observed. This is for example possible in public places like malls, etc. As mentioned before, the decision for one observation method is directly connected to the question what the point of interest is for the organization and who the observers are.

Step II - Collection of Data

Generally in the empathic design method people are rather observed than asked. But during the observation the observer often asks open questions to gather further information and data. Possible questions in this context could be for example "Why are you doing that?", "How does it feel using the product?", etc. In addition to that the observer very often has a catalogue of questions for himself while observing. These questions could include for example "What problems does the user have when opening 
the package?", "In which order does the consumer use the different parts of the product?", etc. This internal questionnaire is defined before the observation and therefore leads the different observers to pay attention to the important points. Furthermore after the observation this leads to comparable protocols of the observation and then in sum can lead to interesting insights. In addition to that also video and photographs can be used for gathering information. Looking at videotapes after the observation again gives the possibility to have a deeper look at the consumer and to find out, e.g., when the consumer hesitates (also for only a very short time) or which movements in detail the consumer makes. In the author's view the combination of the different protocols of the observation from different observers and the repeated look under several points of view at the video tapes can boost the results of the empathic design method.

Step III - Analysis and Interpretation of Data

After having collected data in different ways they are brought together and discussed among the observers. The observers focus on what they discovered and work out together the most important or most urgent problems of the consumer using the product. They define the features of the product which have to be improved as a result of the observation. And as one of the most important results of the overall observation, they look for first ideas of new products and innovations which they derive from the observed habits of the consumer (Lüthje, 2003). 


\section{Step IV - Development of first Solutions}

After having gathered the information, the observers work together and search for new ideas and possible solutions. Generally different methods of creativity can be used. One very common way of bringing up new ideas in a first step is brainstorming. Many ideas, being realistic or not, are produced during such a session. All of these ideas are documented and afterwards evaluated. After having evaluated and prioritized these ideas, first prototypes are built. These prototypes can be either virtual prototypes like simulations (e.g. the new design of a factory or a supermarket) or drawings or real touchable products, depending on what the targeted product is. The more specific the prototype is the easier it is to discuss it with existing or potential customers. This is the moment when the "regular" innovation process in an organization starts and which, depending on the organization can be very different. But having used the method of empathic design for generating the ideas for innovation projects, the chance of creating a product which is successful and well accepted by the consumers is very high.

Leonard and Rayport even identify five key steps in empathic design. In comparison to the model above they add another step between step four and five which is called "brainstorming for solutions" (Leonard, Rayport, 1997). In the author's view this step is reasonably included in step four in the model above as this brainstorming is part of the process of developing first ideas for new products or solutions. 


\subsubsection{Gained Information by Empathic Design}

Using Empathic Design Leonard and Rayport identify five types of information which can be gathered using observation in the empathic design method (Leonard, Rayport, 1997).

\section{Triggers of Use}

What are the real reasons for the customer to use your product? Are these reasons really those you expected in your market analysis when you entered the market? And even more important: Are the marketing activities of the organization really meeting the market in the way the consumers use the product? Finding out what the product is really used for can give the organization important insights about niches for new products. The big advantage of developing products for these niches is that the potential market already exists, as people are using other products to satisfy their needs. Leonard and Rayport give the example of the producers of the cereals Cheerios, who found out that their cereals were not only used for breakfast. Another important usage of the product is that parents of small children use Cheerios as little snacks for their children when they are not at home to calm them. In their view the advantage for this use is the packaging and the possibility to pack Cheerios and the size of the single cheerio as a small snack every time everywhere (Leonard, Rayport, 1997). 


\section{Interactions with the User's Environment}

How does the customer use the product in his own private environment? In combination with which other products is the product used? Empathic design can give important insights on this question no matter whether the products purpose or use is for private or business use. It gives the organizations ideas which interfaces to other products and if those are well developed or if there is a need for an improvement or even a new product which therefore has a unique selling point. But therefore customers have to be watched using the product in their own environment.

\section{User Customization}

The question is if and how the user changes the product in a way that it better fits his personal needs. Does the customer add something to the product or reduce something? Organizations can gain a lot of information on how products can be designed in the future, how they can be improved or even how new products could look like. Leonard and Rayport give the example of a design studio of Japanese car manufacturers who opened a design studio in California. There car fanatics can change cars to their wishes (motor, exterior, interior design). These test persons give the developers of the car manufacturers insights about possible models for the future (Leonard, Rayport, 1997). 


\section{Intangible Attributes of the Product}

What kinds of intangible attributes does the existing product have that attract the customer? Generally customers cannot or do not want to name these reasons when they are asked in a survey or e.g. in a focus group. Very often these arguments have a personal or emotional side which is decisive for a product. Leonard and Rayport give the examples of cleaners and detergents. The smell of the products is the real satisfaction when using them, because customers know that smell from the past, or it gives them the impression of cleanliness. In contrast to that the authors give the example of more environmentfriendly cleaners that fail in the market because the clothes do not have the expected smell after washing. Not knowing these subconscious demands of the customers can destroy the success of a new product (Leonard, Rayport, 1997).

\section{Unarticulated User Needs}

For an organization using empathic design it is the highest target to find unarticulated needs or wishes of the customer. Those wishes are only latently existing but offer a huge potential for new products. It is the task to find out what people do and how they do it and how an improvement would be highly beneficial for them. Therefore the solutions for the needs do not necessarily need new technology. Leonard and Rayport give the example of Nissan finding out by looking at users of minivans that their original use was to have space for transporting things. But the seats of minivans until that point of time always had to be built out of the car which was taken as a given fact by the customer. Nissan as the first producer used the existing technology of sliding the back seats forward 
and this way create large space in the back for transportation. Another example is the development of the Gillette Lady Sensor. Over a long period of time women were dissatisfied with inappropriateness of men shavers for the needs of women. After redesigning the product as a new product for women this product exactly met the needs of the female customers and therefore was a huge success for the company (Leonard, Rayport, 1997).

Generally the process of emphatic design should lead to an idea and later to a product which exceeds the customers' expectations. These ideas are very often latently existing in customers minds but cannot be explicitly be articulated. The big advantage of these (product-) ideas is that, once they are clearly and reliably found out, the probability of success is comparably high in comparison to the overall percentage of success of new products.

\subsubsection{Lead User Method}

In successful organizations the realization of incremental innovation projects is routine work. The management can choose from a large variety of methods with which these projects can be systematically planned, managed and controlled. Therefore the traditional ways of market research offer many possibilities to determine customers' needs and to test the developed concepts in the target markets even before bringing the products to the market.

The situation is completely different in projects for radical innovations, which are also called "breakthroughs". The traditional market research methods only offer a limited 
possibility to find out the future needs of the market and the needs of future products. On the one hand this has its reason in the methods themselves which give the customers only limited possibilities to articulate the innovative ideas out of their perspective. On the other hand this has its reason in the existing customers themselves who are integrated in the processes of market research as they generally stick to the existing products and solutions. Only very randomly they are able to disengage themselves from the existing status and can describe future needs and demands.

This is the reason why many organizations today work together with extraordinarily qualified and progressive customers and other people who are called Lead Users. They differentiate themselves fundamentally in their motivation and qualification for innovation from "normal" customers. The identification and integration in the innovation process is the main part of the lead user method.

\subsubsection{Limitations of Market Research}

For the long-term success of an organization, a well-balanced portfolio of incremental and breakthrough innovations is needed. As already described, the process of continuous improvement of existing products and services is a less of a problem than the management of breakthrough innovations. The reason for that lies in the representative selection of existing customers. With their input the organization tries to identify ideas for innovations. This approach generally leads to dissatisfaction in the researching organization regarding breakthroughs as the customers generally only produce small improvements for existing products. These improvements are necessary for the existing 
portfolio but do not lead to radical new ideas for innovations. The experiences of the customers with the existing products limit their ability to think about the solutions and products in the future. Eric van Hippel calls this phenomenon "functional fixedness" (von Hippel et al., 1999). Organizations which follow in their strategy only the results of representative studies are in danger that their portfolio becomes obsolete and the organizations will be squeezed out of the market in the long run. This is the reason why successful organizations like 3M, HILTI, Nortel Networks or Kellogg's more and more rely on the cooperation with lead users in the early stages in the innovation process. The main target of this approach is to produce ideas for breakthrough innovations.

\subsubsection{Definition of Lead Users}

Lead users are extraordinarily qualified and progressive users who are both motivated and qualified to contribute in a sustainable way to the development of radically new products or services (von Hippel, 1988). Lead users are characterized by two characteristics:

1. They feel the need of future products which will be widely accepted in the market in the future, and this much earlier than the mass of the consumers.

2. They benefit in a high degree from the innovations as these are the solution for their existing problems and solve their (future) needs. 


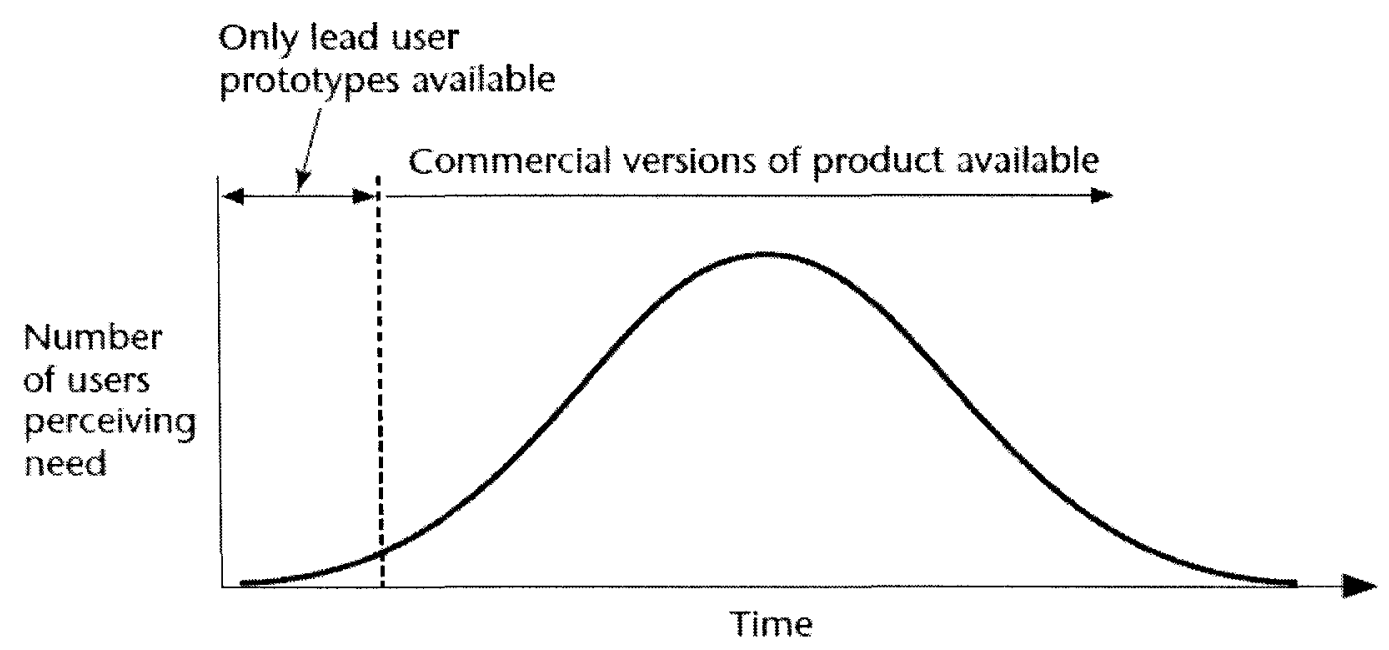

Figure 20. Innovations by lead users precede equivalent commercial products (von Hippel, 2005)

Through their pioneering task in the context of new demands and future usage problems lead users can be used as a kind of radar for the future needs of the complete market. In comparison to normal users they do not have to put themselves in a future situation of usage. Lead users have the feeling of needs and demands of the mass of the people already today. Furthermore, lead users are highly motivated to innovate themselves because there are no existing solutions provided by the industry. The old saying "necessity is the mother of invention" seems very fitting to the motivation of lead users. This constraint to help themselves is a phenomenon in reality which occurs quite often as industries often do not (yet) evaluate the needs of small customer groups correctly. 


\subsubsection{Motivation of Lead Users}

Generating new ideas is most of the times based on some kind of commercial interest. People or organizations innovating have a monetary interest in following their ideas. That results in the question why lead users should be willing to work together and talk for free with an organization which is planning to commercialize the outcome of this cooperation afterwards. Referring to Eric von Hippel there are two major reasons for that (von Hippel et al. 1999):

1. Generally lead users work in other fields which do not directly compete with the researching organization. Therefore lead users are not in a competitive situation with the organization and therefore are very often willing to share their knowledge and experience. Generally they feel satisfaction from the fact that someone is interested in what they have developed and therefore are willing to share their experience.

2. The second reason why lead users are willing to talk to researching organizations is that they feel a strong need for the innovation. They have a high interest that their ideas and improvements are realized as they expect large improvements for themselves through the availability of the product / solution they have in their minds. As in the view of Eric von Hippel lead users are generally very openminded people they are willing to talk to a possible supplier in their view (von Hippel, 1988).

As Eric von Hippel points out it is very important at the beginning of a lead user process to inform the lead user about the intention of the researching organization, that it is their 
intention to develop ideas for future products and that they themselves will commercialize the outcome of the lead user process. If this is a restriction for a lead user he cannot accept and as a result hesitates to share his ideas one should look for other lead users as this would otherwise disturb the innovation process.

\subsubsection{Examples of Lead User Driven Innovations}

The existence of lead users can be demonstrated with a number of innovations which were initiated by the users of the products or services and which were at the very beginning realized without help of or cooperation with the producing industry. These kinds of customer driven innovations are both existing in consumer and business-tobusiness markets.

A very famous example of an innovation by consumers is "Tipp-Ex" which was developed by a secretary in the late 1950 's. This innovation was later further developed by $3 \mathrm{M}$ and industrialized. Another example is the sportive soda "Gatorade" which was developed by trainers of a football team at a college. Generally one can state that the leisure and sports market is full of innovations which were developed by lead users. New existing types of sports are mainly developed by athletes. In research studies of innovations in the fields of oudoor activities like skateboarding, snowboarding, surfing and kite-surfing it has been found out that to a very high percentage the basic ideas and developments have been generated by sportsmen and not by the producers of sport articles (Lüthje, 2004; Franke and Shah, 2003). 
Also in industrial markets many users are capable of important innovations. Eric von Hippel found out that that the main steps in the development of electronic semiconductors have been forced by the producers of the semiconductors and not by the developers of the relating process technologies (von Hippel, 1977). Other active users in the context of innovation could also be found in the medical field of industry when improving medical images (von Hippel, 1999). 
More examples of user driven innovations are shown in the following figure:

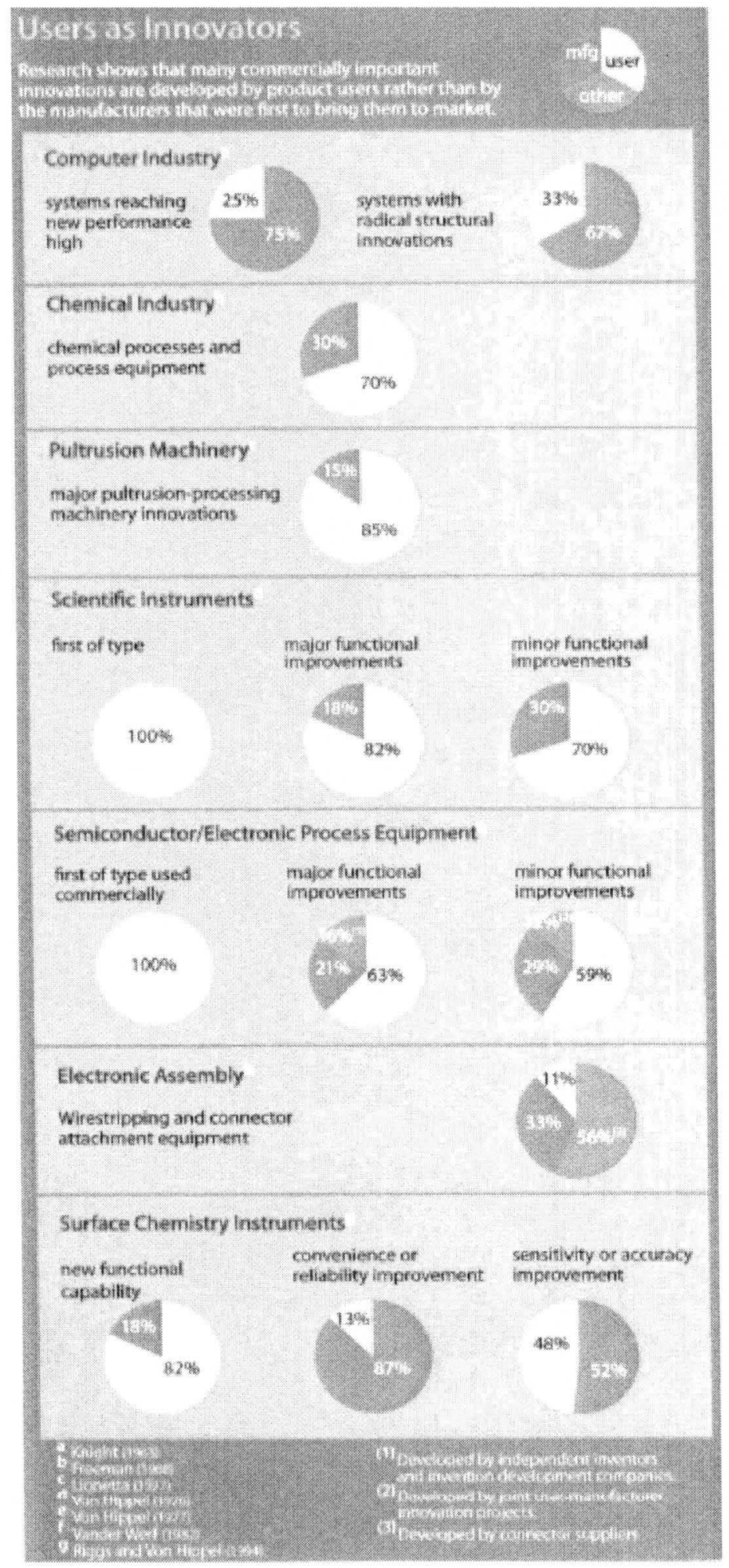

Figure 21. User driven innovations (reprinted from von Hippel et al., 1999) 
Even in the highly dynamic IT-sector one can find several examples for innovations which were developed by users themselves. Two very prominent examples of the "opensource-movement" are the operating system "Linux" and the server-software "Apache". These projects were initiated by individual software users (Linux: Linus Torvald, Apache: Rob McCool) and later accepted by important and large user groups. User communities test and improve these programs themselves and decide themselves about the integration of new program codes into the software. Even if the marketing of these products is taken over by companies (e.g. Linux: VA Linux Systems, Red Hat Inc.) those companies have practically not been involved in the development of the product.

Those examples for user driven innovations bring up the question which role the producing industry in this process has to play. Only if the right lead users can be identified and integrated in the process of innovation an organization has the chance to participate from the huge potential of their ideas.

\subsubsection{Design of Lead User Process}

In the 1980's the MIT-Professor Eric von Hippel developed a first systematic approach for the search of innovative users. The resulting lead user method since then has been used for many applications and has been developed further and in detail. The procedure nevertheless consists of a multi-step process which starts with the definition of an area of interest and ends with the development of product ideas. According to Eric von Hippel the usual lead user process takes between four and nine months (von Hippel et al. 1999) 


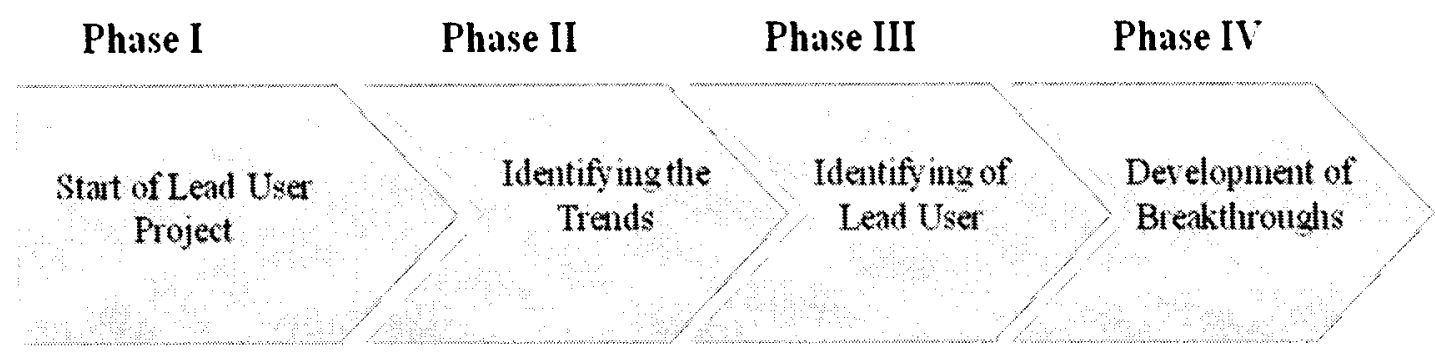

Figure 22. Lead User Process (The author's illustration)

\section{Phase I - Start of Lead User Project}

Generally a lead user project is too challenging as to be handled beside the daily routine work. This is the reasons why an interdisciplinary team with members from the departments marketing, research and development and production should be formed. Depending on the individual structure of the organization of course representatives from other departments which are important have to join the team. In sum the team should have three to six members who can use about $50 \%$ of their working time for the lead user project (von Hippel et al., 1999).

The project team starts with the definition of the area of interest. This can either be a market or field of products or services in which it is interesting for the organization to create innovative ideas. In the formulation of the targets it is important to clearly define which basic requirements the developed ideas have to follow. An example in this context could be the degree of novelty. Furthermore the general project framework including budgets, developing times, etc. which has an influence on the realization of the project has to be agreed on (von Hippel et al., 1999). 


\section{Phase II - Identifying the Trends}

Lead users are the pioneers in important trends and developments. This is the reason why they feel the needs for new products or solutions earlier than other users. Therefore at first the technology and market trends which are important and decisive for the field of interest have to be prognosticated. Depending on the field of interest also economical, legal and social developments and trends have to be taken into account. If these trends are defined the team can start searching for lead users fitting to their needs.

Different sources for the trend analysis can be used. In the lead user method especially talking to experts in certain fields has led to good results. In the search for experts one should broadly spread the included knowledge of experts in order not to overlook decisive developments in the field of interest (e.g. competitive technologies, new developing markets). Beside insights about important trends very often at this point of time one gets first ideas about possible lead users. This is due to the fact that the involved experts are also a first contact point for the lead users in their search of partners and supporters.

\section{Phase III - Identification of Lead Users}

For identifying the lead users the project team as a first step has to define indicators which characterize innovative users in a good and proper way. Especially regarding the determined trends which were identified in phase II, the lead users should be leading pioneers in those trends and developments. The process of searching the lead users is a 
creative process which has to be adjusted to the individual requirements of the field of interest. Generally in the search for lead users one differentiates between two approaches:

\section{Screening}

If a large number of product users exists one works comparably to a dragnet investigation. The presence of defined characteristics of lead users is checked within the group. The screening of possible lead users gets more and more detailed until a small number of fitting lead users are identified. The following figure shows an example in the field of the automotive industry:

Field of Interest Body Construction in Automotive Industry

Trends
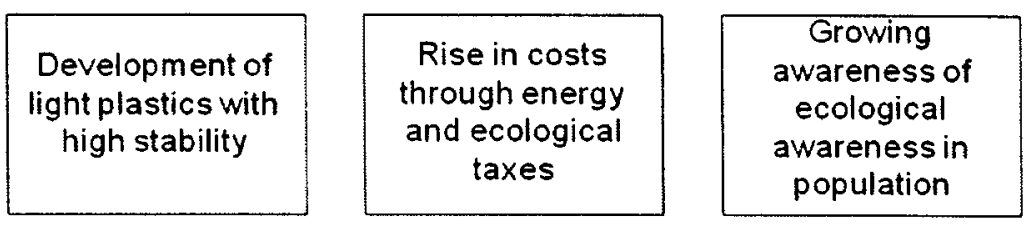

\section{Characteristics of Lead User}
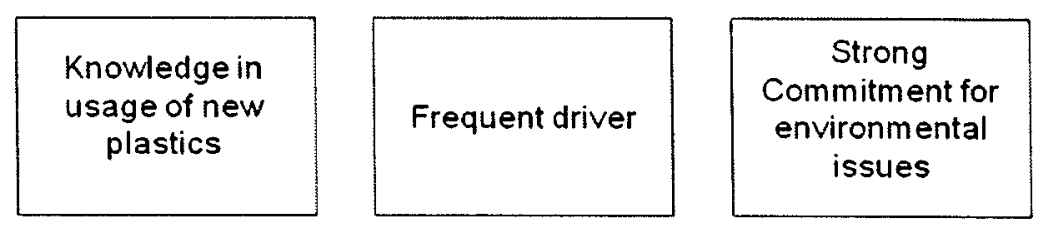

Example of a Lead User

Ecologically minded taxi driver who builds model airplanes in his leisure time

Figure 23. Example of a lead user identification (The author's illustration) 


\section{Networking:}

In the networking approach some selected customers are integrated in the project and asked if they know other product users who have other needs of the existing product or have been innovative in changing the existing solution themselves. Generally this mouth to mouth propaganda very quickly leads to the interesting lead users. Another advantage of this method is that very often one is referred to analogous branches where similar tasks have to be fulfilled or similar products are used. Eric von Hippel relies in this context to the lead user project at $3 \mathrm{M}$ "medical imaging" which had the task of early diagnosis of very small tumors. In the process of searching not only leading radiologists but also experts from the military were integrated as lead users. The reason was that for the identification of details (e.g. weapons) on satellite pictures the military uses software which is able to detect patterns even if the solution of the picture is not too high. This approach was completely new for the medical imaging project as in this project they had only worked on increasing the solution of the picture (von Hippel et al., 1999).

The following figure shows the idea behind the networking approach in identifying the lead user. 


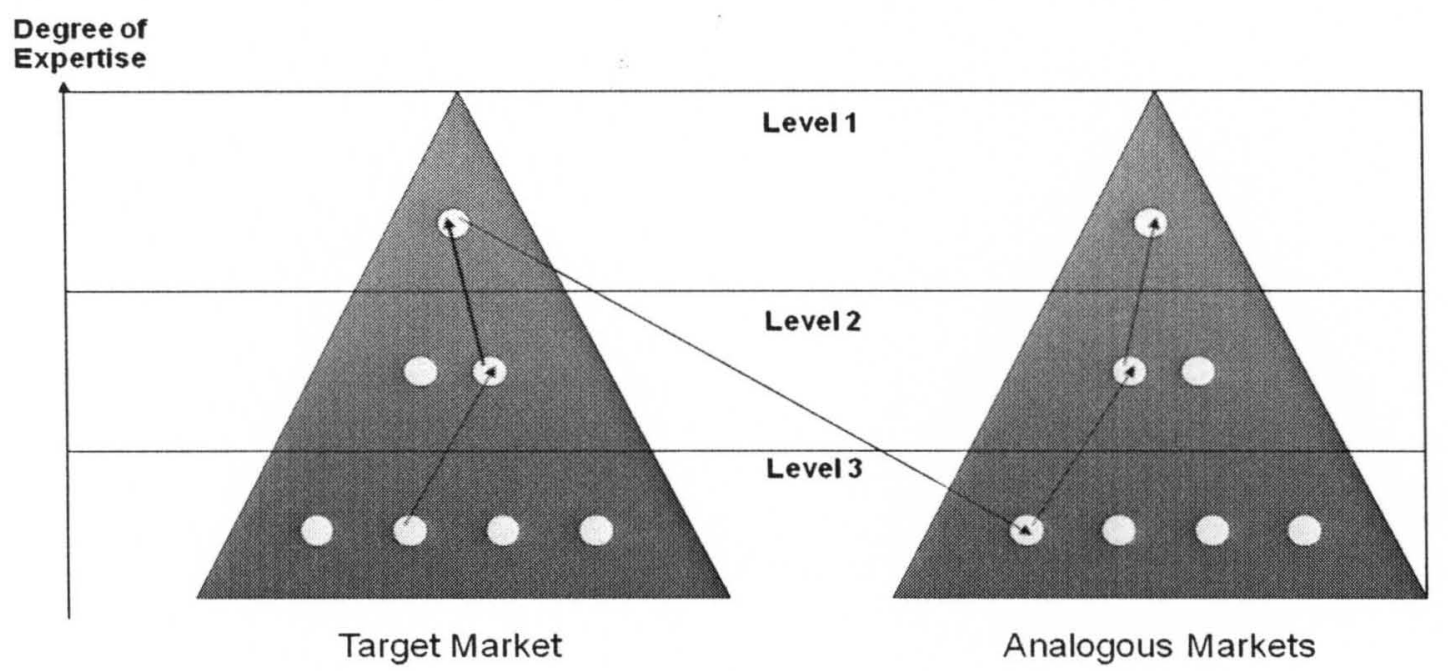

Figure 24: Search for lead users by networking approach (Lüthje, 2003)

\section{Phase IV - Development of Breakthroughs}

In a workshop which generally takes two to three days all identified lead users are brought together. In this workshop they develop ideas or combine different ideas with each other. Depending on the field of interest the researching organization has to clarify in advance of the workshop how they will deal with the intellectual property rights. As already mentioned, generally lead users are willing to assign their rights of the ideas to the researching organization without any noteworthy monetary gratuity.

The workshop begins with working out the problems with existing products or solutions and the definition of demands on future products. This discussion should be supported by different methods of creativity and the results afterwards are the basis for the development of concrete innovation ideas. These ideas are worked out in teams of three 
to five persons. At the end those ideas should be substantiated by e.g. descriptions of the concept, drawings or models.

After the workshop the ideas have to be evaluated and have to be presented to the management of the researching organization. If the management decides that one project should be followed further, it is integrated in the existing innovation process in the organization. Therefore the lead user method is not an alternative for the existing methods of innovation management or the market research but a method to find success promising ideas for new innovation projects and future products. 


\section{CHAPTER 3 - RECOMMENDATION MATRIX}

3. Recommendation Matrix for Usage of Methods

\subsection{Factors of Differentiation between Methods}

The described methods all involve customers at a very early stage in the innovation process. Therefore the chance of success of the resulting product should be raised. In the view of an organization which has limited resources the basic question is which method should be used and started as an innovation project.

The following matrix compares the described methods in some selected factors, which can help the organization in the decision between the different methods: 


\begin{tabular}{|c|c|c|c|}
\hline & $\begin{array}{l}\text { Models for } \\
\text { Positioning }\end{array}$ & $\begin{array}{l}\text { Empathic } \\
\text { Design }\end{array}$ & Lead User \\
\hline Complexity of method & Moderate & Low & High \\
\hline Expected degree of novelty & Moderate & Low & High \\
\hline $\begin{array}{l}\text { Need of outside resources in } \\
\text { project (except test persons) }\end{array}$ & Low & Moderate & Moderate \\
\hline $\begin{array}{l}\text { Applicability of results on existing } \\
\text { portfolio }\end{array}$ & Moderate & High & Low \\
\hline $\begin{array}{l}\text { Availability of qualified test } \\
\text { persons for the method }\end{array}$ & Moderate & High & Low \\
\hline $\begin{array}{l}\text { Probability of quick applicable } \\
\text { results }\end{array}$ & Moderate & High & Low \\
\hline Coordination effort & Low & Moderate & High \\
\hline Needed internal time resources & Low & Moderate & High \\
\hline Cost of Method & Moderate & Moderate & High \\
\hline Risk of knowledge transfer & Low & Moderate & High \\
\hline
\end{tabular}

Table 1. Factors of Differentiation between Methods (The author's illustration)

Comparing all the factors of differentiation, the efforts regarding e.g. costs, complexity and needed internal and external personnel, the effort for the lead user method is the highest for the organization. But on the other hand the expected degree of novelty and therefore the potential for discovering new and highly profitable markets is the highest using the lead user approach in comparison to using models for positioning or the 
empathic design approach. These two aspects have to be balanced by the organization when it finally decides between the mentioned methods.

Before that the organization has to think wisely about which statements of the following recommendation matrix fits best to its current innovation motive and innovation target. Even if an organization finds out through the statements in the following recommendation matrix that a lead user project would perfectly fit to their motives of innovation, it is advisable to recheck with the factors of differentiation if the organization is able and wants to take all the efforts like time and money needed in the lead user method before starting the project.

\subsection{Recommendation Matrix}

The target of this thesis is to offer recommendations for organizations to help them to find the right decision regarding a method for finding ideas for innovations. What can be decisive factors in order to give recommendations for organizations? In the author's view the recommendations do not depend on how large or small the organization is, if it is working in a B-B or B-C Market or if it is working in a niche or in a mass market. If an organization is willing to innovate it is important that before it decides for one method and starts an innovation project it is aware of the targets the organization wants to reach with this innovation project. Therefore the recommended method depends on what the organization wants to achieve. In the matrix the left column contains possible statements of motivation for innovation projects of an organization. Given that these statements are true the recommended method for bringing up suitable innovation ideas is marked with a 
"+". If there is an alternative method which in the author's view could also provide at least some innovation ideas, this method is marked with a "O". Methods which are not recommended because in the author's view they do not fit for the innovation targets of the organization are marked with a "-"." 


\begin{tabular}{|c|c|c|c|}
\hline & $\begin{array}{l}\text { Models for } \\
\text { Positioning }\end{array}$ & $\begin{array}{c}\text { Empathic } \\
\text { Design }\end{array}$ & Lead User \\
\hline $\begin{array}{l}\text { The organization wants to develop a } \\
\text { new product to replace an existing } \\
\text { product. }\end{array}$ & & + & + \\
\hline $\begin{array}{l}\text { The organization wants to develop } \\
\text { innovative products in addition to its } \\
\text { existing portfolio for the existing } \\
\text { market. }\end{array}$ & + & & \\
\hline $\begin{array}{l}\text { The organization searches for } \\
\text { innovative applications or markets for } \\
\text { its existing product. }\end{array}$ & & & + \\
\hline $\begin{array}{l}\text { The organization wants to develop a } \\
\text { completely new product } \\
\text { (breakthrough innovation) to expand } \\
\text { its business in the long run. }\end{array}$ & & & + \\
\hline $\begin{array}{l}\text { The organization is in need of quick } \\
\text { innovative features for existing } \\
\text { products e.g. to keep them } \\
\text { competitive. }\end{array}$ & & + & \\
\hline $\begin{array}{l}\text { The optimization of existing features } \\
\text { of a product only leads to minimal } \\
\text { improvements. }\end{array}$ & & & + \\
\hline $\begin{array}{l}\text { The needed raw materials of the } \\
\text { product will not be available in the } \\
\text { future anymore. }\end{array}$ & & & + \\
\hline $\begin{array}{l}\text { The offered product will not be } \\
\text { needed anymore in the future due to } \\
\text { e.g. changes in technology. }\end{array}$ & & & + \\
\hline
\end{tabular}

Table 2. Recommendation Matrix for Usage of Methods (The author's illustration) 


\section{CHAPTER 4 - DISCUSSION}

\section{Discussion of Recommendation Matrix}

Looking at the statements in the recommendation matrix, typically an organization has more than one target which it wants to reach with an innovation project. Therefore the various statements can be suitable for the organization. If the recommended method is the same for the different statements the organization can in addition recheck with the differentiation factors if the organization can also provide the needed internal and external resources etc. If the recommended methods are not the same the factors of differentiation can in addition help the organization to decide for one method or even bring up arguments for using both methods. Generally an organization does have a mix of innovation projects and therefore does have main arguments for the planned single innovation project. Therefore the recommendations for the different motivations should be discussed in detail.

Given the case that an organization primarily wants to develop a new product which in the near future should replace an existing product, it can be helpful to use empathic design. Looking at the consumer using the existing product can easily bring up possible improvements or changes on the product that can give hints for a future product. In this case the main target is to provide the market with a product follower which has an innovative character for the user and in the user's view. Also the lead user method can 
lead to satisfying results as it might bring ideas up which are even more innovative than ideas created by an empathic design project. In this case, the organization has to take the available time and budget into account when it decides between these two methods. If the organization is working in a market with long life time cycles and the existing product is at the beginning of its life cycle, it can be recommendable to start a lead user project in order to possibly enhance the degree of novelty of the future product. On the other hand if the organization does not have the needed time for a lead user project, ideas can be faster generated by empathic design. In this case the model for positioning would probably not be as promising as the other two methods. But given the case that the organization wants to offer more products besides its existing products and markets which are innovative and helpful for the user, models for positioning can give hints for possible niches. They give the possibility to compare different attributes with each other, either with customers or internally in the organization. An example in this case could be do-it-yourself tools. Axes in positioning models could on the one hand be e.g. power and weight of the tool, but, given the case that there is a trend of a rising number of female users, there could also be axes where design is compared to need power, etc. The result could be a completely new product line which follows the needs of a female target group. In this case a combination of these models and some observations would be very helpful, whereas the empathic design approach is at least partly recommendable.

Given the case that the organization is searching for innovative applications or markets for (more or less) existing products all three methods can lead to acceptable results. In this case it depends on the product. If it is some kind of raw material which can be used in different kinds of production processes the lead user approach would on the one hand 
probably be the most complex one and the one that consumes much time and money but on the other hand it could also lead to the most breakthrough ideas or new fields of application. Completely new markets can be found which in general are most promising regarding quantity, turnover and competition. In comparison to that empathic design would focus on the existing consumers which would possibly lead to ideas for niches in the existing market.

A comparable situation can be found if the organization well working products today but is aware of the fact that in the future e.g. some raw material will not be available or not allowed anymore. Then it is advisable to start a lead user project early enough to search for alternatives. This requirement exactly meets the idea of the lead user method. A good example in this context could be the fact that within Europe traditional bulbs will in several steps be forbidden by law from 2009 on due to their low energy efficiency. This fact was known approximately 3 years before. A lamp producing organization needing the design and the light output of a bulb could have started a lead user project in order to develop an innovative product which on the one hand fulfills the energetic demands and on the other hand has the shape and design of a bulb and meets the required light intensity. The empathic design method would in this case not lead any further, whereas models for positioning could help further regarding the comparison of different types of lamps and bulbs, their wattage, their energy consumption, their differences in the spread of light, etc.

As pointed out it is important for an organization that it has a constant and reliable flow of innovations to stay competitive. The relaunch of products with innovative features is one possibility. In this case the empathic design method provides reliable ideas for 
solutions as they are stimulated by the observation of consumers when using the products. This approach is in the author's view very promising at the beginning of the life cycle of a product. At that time the potential for innovation can be very large but decreases in the later stages of the life cycle. Therefore, if the innovative potential of a product is already low and improvements only lead to minimal and barely noticeable improvements a lead user project can be helpful to maybe revolutionize the product or solution, or start thinking in a completely new direction. In this context, refer back again to the example of $3 \mathrm{M}$ in which the optimization of the solution of pictures did not bring any further improvements. Only after using software in order to detect certain patterns, as they do in the military, real improvements regarding the early recognition of tumors were made. 


\section{CHAPTER 5 - SUMMARY AND CONCLUSIONS}

\section{Summary and Conclusions}

All methods integrate the customer at the beginning of the innovation process when ideas for new products or services are generated. This is the first step to enhance the chance of success of the later marketed product. Therefore the use of any of these methods is much better than not to include customers or potential customers at the beginning of the innovation process and to generate ideas and invent products only based on internal ideas and research. It is nevertheless difficult to give exact recommendations as to which case which method should be used in a specific case. Should the recommendation depend on the market in which the company is? Probably not, because the need to innovate exists both in B-B-Markets and in B-C-Markets. Looking at the lead user approach one can see very often lead users come from different types of markets, which is one of the success factors of this method. The empathic design can also work well in both types of markets, even if generally the number of consumers differs. A differentiation between large and small companies also does not seem applicable in the search of the right method. The only limiting factor in this context is the willingness and ability to invest money in the search of innovation. But this does not necessarily depend on the size of the organization. 
It generally does not seem very promising to rely on only one method. The combination of different methods and therefore the idea of having a smooth running overall innovation process in the organization might in the end bring the best solutions. So the organization has to ask itself as to the importance of the statements in the recommendation matrix and in the next five or ten years.

Will the market still exist in the next five or ten years?

What budget does the organization have for the innovation project?

Which method due to its complexity or costs can the organization handle itself with its own personnel?

What time frame for the generating of innovation ideas is acceptable?

And even more important: Is the organization willing to radically change existing structures or products?

Therefore an innovation-friendly environment in the organization has to be implanted and supported by the management. This is the first success factor, because it manifests the general basis for innovation. As all of the approaches generally bring out several ideas for new products and thus for innovation projects it is very important to decide for the right ideas which are followed further and pass the "money gate". Therefore the second success factor is the parallel use of different methods and the combination or even addition of the results of the different approaches to stabilize the decision for the further followed innovation project. This combination of an innovation-friendly environment in the organization, the creative use of methods which include the customers or other test persons right at the beginning of the innovation process and the ability of the 
management to decide for the right mix of innovation projects will in the author's view secure the future of the organization. 


\section{REFERENCES}

1. Berekoven, L., Eckert, W., Ellenrieder, P. (1993). Marktforschung: Methodische Grundlagen und praktische Anwendungen. Wiesbaden: Gabler Verlag.

2. Brockhoff, K. (1999): Forschung und Entwicklung: Planung und Kontrolle. München: Oldenbourg.

3. Cooper, R. G. (1983): A process model for industrial new product development. IEEE Transactions on Engineering Management, 30: p. 2-11.

4. Cooper, Robert G. (1994): Third-generation new product processes. Journal of Product Innovation Management, 11: p. 3-14.

5. Cooper, R. G. (1996): Overhauling the new product process. Industrial Marketing Management, 25, p. 465-482.

6. industrial firms. Industrial Marketing Management, 20: p. 137-147.

7. Cooper, R. G., Kleinschmidt, E. J. (1994). Screening new products for potential winners. IEEE Engineering Management Review, 22 , p. 24-30.

8. Crawford, C. M. (1994). New Products Management. Boston: Irwin, Burr Ridge.

9. Dorbandt, J., Fröhlich, J., Schmelzer, H.J., Schopp R. (1990). Ausgewählte Projektbeispiele zur Reduzierung der Entwicklungszeit, in: Durchlaufzeiten in 
10. der Entwicklung: Praxis des industriellen F\&E Managements. München: Oldenbourg Verlag.

11. Fink, D. (2005). Was macht Innovationen erfolgreich? Wie die richtige Innovationsstrategie den Unternehmenswert steigert. Kronberg: Accenture.

12. Franke, N., Shah, S. (2003). How communities support innovative activities. An exploration of assistance and sharing among end-users. Research policy Vol. 32/1: p. 157-178.

13. Gaiser, B: Bewältigung der Schnittstelle zwischen F\&E und Marketing durch entscheidungsorientierte Information. Stuttgart: Schäffer-Poeschel Verlag.

14. Garcia, R., Calantone, R. (2002). A critical look at technological innovation typology and innovativeness terminology: a literature review. Journal of Product Innovation, 19: p. 110-132.

15. Gerpott, T. (1999). Strategisches Technologie- und Innovationsmanagement. Stuttgart: Schäffer-Poeschel Verlag.

16. Green, G., Gavin, M., Aiman-Smith, L. (1995). Assessing a multidimensional measure of radical technical innovation. IEEE Transactions on Engineering Management, 42: p. 203-214.

17. Hartschen, M., Scherer, J., Brügger, C. (2009). Innovationsmanagement. Offenbach: Gabal Verlag GmbH.

18. Hauschild, J., Salomo, J. (2007). Innovationsmanagement. München: Vahlen.

19. Herstatt, C., Verworn, B. (2003). Bedeutung und Charakteristika der frühen Phasen des Innovationsprozesses. Wiesbaden: Gabler Verlag. 
20. Hughes, G. D., Chafin, D. C. (1996): Turning New Product Development into a Continuous Learning Process. Journal of Product Innovation Management, 13: p. 89104.

21. Johne, F. A., How experienced product innovations organize. Journal of Product Innovation Management, 1: p. 210-223.

22. Khurana, A., Rosenthal, S.R. (1998).Towards holistic „front ends“ in new product development. Journal of Product Innovation Management, Vol.15/1: p. 57-74.

23. Kobe, C. (2003). Technologiebeobachtung. Wiesbaden: Gabler Verlag.

24. Kotler, P. (1999). Marketing-Management: Analyse, Planung, Umsetzung und Steuerung. Stuttgart: Schäffer-Poeschel Verlag.

25. Kotler, P., Bliemel F. (1999). Marketing-Management. Stuttgart: Schäffer-Poeschel Verlag.

26. Leonard, D., Rayport, J.F. (1997). Spark innovation through empathic design. Harvard Business Review, Vol. 75/6: p. 102-108.

27. Lüthje, C. (2003). Methoden zur Sicherstellung von Kundenorientierung in den frühen Phasen des Innovationsprozesses. Wiesbaden: Gabler Verlag.

28. Lüthje, C. (2004). Characteristics of innovating users in a consumer goods field: An empirical study of sport-related product consumers. Technovation Vol. 24/9: p. 683695.

29. Moenart, R.K., Deschoolmeester, D., Demeyer, A., Souder, W.E. (1990). Information styles of marketing and $\mathrm{R} \& \mathrm{D}$ personnel during technological product innovation projects. R\&D Management Vol. 22/1: p. 21-39.

30. Nieschlag, R., Dichtl, E., Hörschgen, H. (1997). Marketing. Berlin: Duncker \& Humblot. 
31. Nobelius, D., Trygg, L. (2002). Stop chasing the front end process - management of the early phases in product development projects. International Journal of Project Management, Vol. 20/5: p.331-340.

32. Pleschak, F., Sabisch, H. (1996). Innovationsmanagement. Stuttgart: SchäfferPoeschel.

33. Reichwald, R., Piller, F. (2009). Interaktive Wertschöpfung. Wiesbaden: Gabler Verlag.

34. Ulrich, K. T., Eppinger, S. D. (1995). Product design and development. New York: McGraw-Hill.

35. Urban, G.L., Hauser, J.R. (1993). Design and marketing of new products. Englewood Cliffs, NJ: Prentice Hall.

36. Vahs, D., Burmester, R. (1999). Innovationsmanagement. Stuttgart: SchäfferPoeschel.

37. Vahs, D., Burmester, R., (2005). Innovationsmanagement. Von der Produktidee zur erfolgreichen Vermarktung. Stuttgart: Schäffer-Poeschel Verlag .

38. Von Hippel, E. (1977). The dominant role of the user's in semiconductor and electronic subassembly process innovation. IEEE Transactions on Engineering Management, Vol. 24/2: p. 60-71.

39. Von Hippel, E. (1986). Lead users: a source of novel product concepts. Management Science Vol. 32/7: p.791-805.

40. Von Hippel, E. (1988). The sources of innovation. New York: Oxford University Press. 
41. Von Hippel, E., Thomke, S., Sonnack, M. (1999). Creating breakthroughs at 3M. Harvard Business Review No. 5: p. 3-9.

42. Von Hippel, E. (2005). Democratizing Innovation. Cambridge MA: The MIT Press .

43. Whiteley, R. L., Bean, A. S., Russo, M. J. (1998). Using the IRI/CIMS R\&D Database. Research Technology Management, 41: p. 15-16. 


\section{CURRICULUM VITAE}

NAME: $\quad$ Philipp Andreas Cimander

ADDRESS: $\quad$ Sommerleite 23

97318 Kitzingen

Germany

DOB: $\quad$ Germany, Würzburg - July $1^{\text {st }} 1978$

EDUCATION \& - Diploma in Business Administration

TRAINING University of Applied Sciences, Heilbronn

$1999-2004$

- Exchange Student

Waterford Institute of Technology, Ireland 2001

- A-Levels

Friedrich-Koenig-Gymnasium, Würzburg, Germany $1989-1998$

AWARDS: $\quad$ Best degree holder at University of Heilbronn in Business

Administration in 2004

LECTURING

- University of Applied Sciences, Heilbronn, Germany

EXPERIENCE: $\quad 2005$ - present

- University of Cooperative Education, Eisenach, Germany

$2007-2008$ 
PROFESSIONAL

EXPERIENCE:
- Knauf Gips KG, Iphofen, Germany

Head of Key Account Programms

2009 - present

- Knauf Gips KG, Iphofen, Germany

Product Manager for Drywall Systems

$2004-2009$

- INA-Schaeffler KG, Herzogenaurach, Germany

Diplomand in the field of gear shifts in the automotive sector

$2003-2004$

- Pratley International, New York

Intern in promotion of Economic Development

$2002-2003$ 